\title{
BEHAVIORAL PORTFOLIO THEORY AND BEHAVIORAL ASSET PRICING MODEL AS AN ALTERNATIVE TO STANDARD FINANCE CONCEPTS
}

\author{
Miljan Lekovic* \\ Faculty of Hotel Management and Tourism in Vrnjačka Banja, University of Kragujevac, \\ The Republic of Serbia
}

The growing gap between standard finance theory and practice has made way for the emergence of new theories and the development of new asset-pricing models. Behavioral economists have seized this opportunity to promote their ideas and thus develop behavioral finance theory, as an antithesis to standard finance theory; behavioral portfolio theory, as an antithesis to modern portfolio theory, and a behavioral asset-pricing model, as an antithesis to standard financial asset-pricing models. The paper aims to illustrate these new theoretical frameworks, given the absence of research at the national level relating to behavioral portfolio theory and the behavioral asset-pricing model. The objective is to explain the key features of behavioral portfolio theory and the behavioral asset-pricing model by means of conducting a comparative analysis of the mentioned theory and its model and standard financial concepts and models. By using a qualitative research methodology, the author concludes that, by incorporating psychological factors, behavioral portfolio theory and the behavioral asset-pricing model complement conventional financial concepts and bring finance theory closer to reality. It is, however, still too early and exaggerated to a certain extent to speak about the superiority of these new theoretical frameworks in relation to modern portfolio theory and conventional asset-pricing models, which is also the main finding of the research study.

Keywords: behavioral finance, psychological factors, mental account, utilitarian benefits, expressive benefits, emotional benefits

\section{JEL Classification: G40, G41}

\section{INTRODUCTION}

Behavioral finance is a new approach to the finance field (Brajković \& Peša, 2015), which examines the role,

* Correspondence to: M. Lekovic, Faculty of Hotel Management and Tourism in Vrnjačka Banja, University of Kragujevac, Vojvodjanska 5A, 36210 Vrnjacka Banja, The

Republic of Serbia; e-mail: m.lekovic@kg.ac.rs importance and impact of psychological factors on the behavior and decision-making of investors, portfolio managers, financial experts and other market participants (Muradoglu \& Harvey, 2012; Bakar \& Yi, 2016). Unlike standard finance theory, which builds on the concept of perfect rationality, behavioral finance is based on a much more realistic concept of bounded rationality, introduced in economic theory by H. A. Simon (1955). 
The behavioral finance postulate is the assertion that investors have cognitive biases which, in fact, are imperfections in their perceptions of reality (Blanco, 2017), resulting in systematic errors in judgment and irrational decisions. Behavioral finance seeks to understand investors, their behavior and decisionmaking processes. In this regard, a normal investor is assumed to be an ordinary man, who is not always perfectly informed and who, under the influence of cognitive biases and misleading emotions, does not always make rational decisions. According to W. F. M. De Bondt, Y. G. Muradoglu, H. Shefrin and S. K. Staikouras (2008), if members of the academic community are to understand financial institutions and actors, and if economic policy makers and actors are to make wise decisions, they must take into account the true nature of people, their imperfections and bounded rationality.

Acquired knowledge in the field of behavioral finance should assist financial decision-makers in identifying and understanding their own mistakes, learning from such mistakes and, most importantly, avoiding making the same mistakes in the future (Muradoglu \& Harvey, 2012; De Bondt, Mayoral \& Vallelado, 2013). Behavioral economists point out the fact that financial theory has been significantly improved with the emergence of behavioral finance, which has "shed light" on financial decision-making processes.

With this in mind, Behavioral Portfolio Theory (BPT) and the Behavioral Asset-Pricing Model (BAPM), as the building blocks of behavioral finance, are the subject matter of the research study presented in this paper. By incorporating psychological elements and side-stepping too restrictive assumptions inherent in standard finance theories and models, the BPT and BAPM seek to explain the actual process of financial decision-making and asset-pricing. The mentioned models are the topic of a number of studies written by foreign authors (Hirshleifer, 2001 Shefrin, 2008; Rengifo, Trendafilov \& Trifan, 2014; Statman, 2014; Pfiffelmann, Roger \& Bourachnikova, 2016; Chandra \& Thenmozhi, 2017; Statman, 2017a; Statman, 2017b; Barberis, 2018). These models, however, have not yet been sufficiently researched by authors in Serbia, which is the motivation lying behind carrying out an adequate qualitative analysis.
The main aim of the research study is to illustrate these relatively recent, still unexplored, theoretical frameworks in the domestic scientific literature, which have been developed as an alternative to standard finance theory. The objective is to inform the investment public in the country on behavioral finance and related advancements in the knowledge of it, which can be very useful to investors, portfolio managers and other market participants. The purpose of studying the BPT and BAPM is to examine this new approach and the original point of view introduced by behavioral finance in the finance field, which, in a way, makes finance theory complete.

The expected outcome of the research is to improve the understanding of the psychology-based portfolio theory and asset-pricing model, including a useful identification and an outline of the key differences between the BPT and Modern Portfolio Theory (MPT), i.e. BAPM and standard financial asset-pricing models.

In accordance with the defined subject matter, the aim and the expected outcome of the research study, the initial hypothesis reads as follows:

$\mathrm{H}$ : Behavioral portfolio theory and the behavioral asset-pricing model bring financial theory closer to reality by incorporating the concepts of mental accounting, bounded rationality, expressive and emotional benefits and arbitrage limitations.

A qualitative research methodology is applied in the paper, which allows for the theoretical verification of the initial hypothesis and the formulation of valid conclusions on the analyzed topics, based on the study of the relevant literature.

Given the defined subject matter and aim of the research, as well as the initial hypothesis, the introductory considerations are followed by prospect theory, as well as Security-Potential/Aspiration (SP/A) theory, which are presented in the paper as the foundations of the BPT development. This section is then followed by the analysis of the key features of the BPT. For the purposes of an easier understanding and/or comprehension, these features 
are described by conducting a comparative analysis of the BPT features and the features of the MPT. After concluding this section of the paper, BAPM is explained as a model developed as an alternative to conventional asset-pricing models, with an emphasis on the influence of psychological factors on investment decisions and asset-pricing. Finally, the positions on the confirmation of the initial hypothesis are summarized, the research limitations are outlined and the topics important for future research are analyzed in the last Conclusion section of the paper.

\section{PROSPECT THEORY AND SP/A THEORY AS THE FOUNDATION OF BEHAVIORAL PORTFOLIO THEORY DEVELOPMENT}

As a part of behavioral finance, behavioral portfolio theory has been developed as an alternative to standard finance theory, i.e. the MPT. Behavioral economists Hersh Shefrin and Meir Statman are considered to be the creators of the BPT. The publication of their paper "Behavioral Portfolio Theory" in the scientific journal "The Journal of Financial and Quantitative Analysis" in June 2000 marked the birth of this new theoretical framework (Shefrin \& Statman, 2000).

H. Shefrin and M. Statman (2000) indicate the fact that two theories of choice under uncertainty, namely prospect theory, formulated by D. Kahneman and A. Tversky (1979), and SP/A theory, developed by L. L. Lopes (1987), served as the foundation of the development of the BPT.

Prospect theory is a descriptive theory of how people make decisions under uncertainty. It is characterized by an asymmetric attitude towards risk. According to prospect theory, there is a difference in terms of the investor's attitude towards risk of gains and risk of losses. An investor reacts differently to equally risky situations, depending on whether such risks are in the gain zone or in the loss zone. In the loss zone, the investor is risk-seeking; however, the same person is risk-averse in the gain zone. Therefore, investors are not solely characterized as risk-seeking or risk-averse; their attitude towards risk varies, depending on a specific situation, i.e. the zone of risk.

The assertion that investors tend to accept risk in the loss zone and avoid risk in the gain zone was corroborated by the findings of the research studies conducted by the creators of prospect theory, D. Kahneman and A. Tversky (1979). The research study included two groups of respondents. The first group, consisting of 70 respondents, were asked to choose between Option A and Option B, where the option A offered a $50: 50$ chance of a $\$ 1,000$ gain or a 0 gain, whereas the option B offered a sure gain of $\$ 500$. The large majority of the respondents $(84 \%)$, chose the option B, thus demonstrating risk aversion tendencies in the gain zone. The second group, consisting of 68 respondents, were offered a choice between Option C and Option D, where the option C offered a 50:50 chance of a $\$ 1,000$ loss and a 0 loss, whereas the option D implied a sure loss of $\$ 500$. The majority of the respondents in this group $(69 \%)$, chose the option $\mathrm{C}$, thus showing risk-seeking tendencies in the loss zone.

The investor's risk-seeking preferences in the loss zone actually are the only way for him to avoid a loss and turn it into a profit, whereas risk aversion in the gain zone is the best way to keep the achieved gains and secure them. In terms of the loss zone, investors are willing to expose themselves to a risk of additional losses in an effort to completely avoid a loss. On the other hand, in the gain zone, investors are unwilling to risk too much in order to increase their gains. Therefore, a typical prospect theory value function is convex below the reference point represented by the origin and concave above it, thus resembling the letter "S" (Figure 1). For example, in the loss zone, investors invest money in lottery tickets, while in the gain zone they buy insurance policies. It is important to note that the value function is steeper in the loss zone than in the gain zone, which is indicative of the fact that investors feel losses more strongly than gains.

In brief, individuals are willing to gamble in the loss zone, but at the same time, they are quite unwilling to do so in the gain zone. It is important to note that, in this context, gains and losses do not imply a 


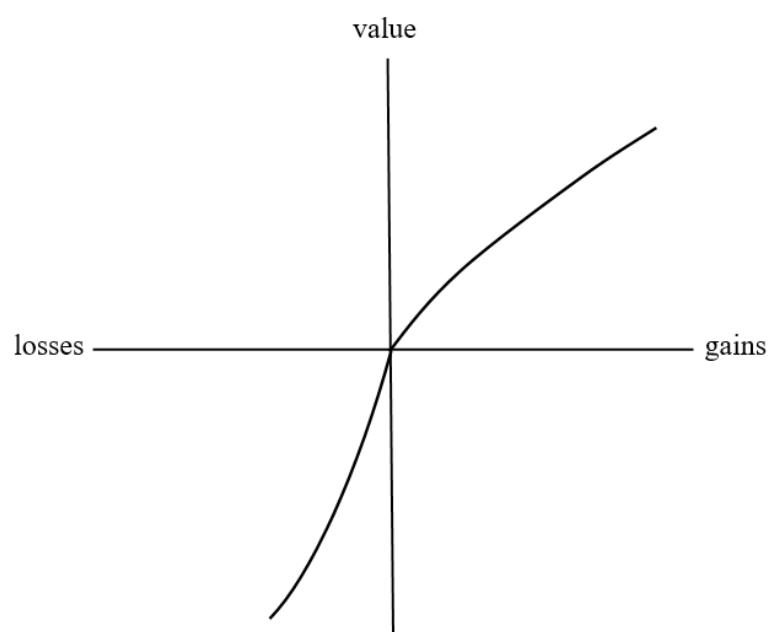

Figure 1 A hypothetical value function

Source: Kahneman \& Tversky, 1979, 279

negative and a positive return, i.e. reducing and/or increasing wealth; these terms refer to wealth below the reference point and wealth above the reference point. The reference point differs from one investor to another, and is determined based on their past experience, underlying their beliefs, i.e. a cognitive bias (anchoring), available information, forecasts. Therefore, it stands to reason that any changes in terms of the reference point affect change in the investor's attitude towards risk, and thus change in the investor's decision. If, due to changes in the reference point, a former loss is perceived as a gain, the investor's risk-seeking behavior will change into risk aversion and they will opt for a less risky investment decision. If, however, due to changes in the reference point, a former gain is perceived as a loss, the investor's tendency to avert risk will be replaced with risk-seeking, thus making them go for an investment decision which carries more risks.

Finally, it should be noted that this theory is an alternative to classical expected utility theory, which is the basis of traditional economic theory, and that it furthermore implies that all investors are risk-averse, for the reason of which fact the utility function is concave for all wealth levels. In contrast to expected utility theory - a normative theory prescribing the rules that every rational and thoroughly informed individual should follow when making a decision, on the one hand, prospect theory is a descriptive theory, on the other, because it describes how individuals make decisions in a real-life business environment (Cupic, 2015, 221). Prospect theory is essentially a critique of utility theory. Pursuant to prospect theory, an individual, based on a specific reference point, considers every available option as an independent and unique event when deciding and makes a decision based on the losses or gains that will be the result of this decision, instead of focusing on maximizing total wealth (Todorović, 2011, 277). Therefore, in terms of prospect theory, the utility function for all wealth levels, which is a feature of classical expected utility theory, is replaced with the value function (of possible outcomes) based on the reference point.

Another theory of choice under uncertainty which was also used as the basis for the BPT development is SP/A theory, initially proposed by L. L. Lopes (1987) and further developed by L. L. Lopes and G. C. Oden (1999). In contrast to the viewpoint of conventional finance theory, which sees people as perfectly rational economic beings, L. L. Lopes (1987) is of the opinion that our everyday decisions, including investment ones, are affected by our emotions, such as fear and hope, as well as our aspirations. Fear governs our concern for security, whereas hope governs our concern for the potential for, i.e. a possibility of, wealth maximization. In this regard, the three basic elements of SP/A theory are: S - security, i.e. our aspiration to escape poverty; $\mathrm{P}$ - the potential, i.e. our desire to reach greater wealth, and A - aspiration, i.e. our striving to achieve a set goal.

As well as prospect theory, SP/A theory belongs to the corpus of descriptive decision theories, because it does not prescribe rules, but rather describes the decision-making process. However, in contrast to prospect theory, which focuses on cognition, i.e. on the cognitive aspects of decision-making, such as framing effects in decision-making relating to the gain or loss zone, SP/A theory emphasizes emotions, i.e. the emotional aspects of decision-making under uncertainty. By stressing the impact of our emotions, SP/A theory provides a general framework for decision-making. According to H. Shefrin (2016), SP/A 
theory strives to equalize interaction between the key emotions, i.e. fear, hope and aspiration.

Furthermore, in contrast to prospect theory, SP/A theory applies two criteria regarding the decisionmaking process: SP - safety-potential, and A aspiration, or decision-makers' ambition. These criteria are independent of each other and often conflicted, because they frequently advocate different decisions. The manner in which this type of conflict will be resolved depends on whether the decisionmaker gives greater importance to the first or to the second criterion, i.e. whether he/she favors fear and hope over ambition, or vice versa.

Highlighting the impact of emotions (primarily fear and hope), the creator of the theory, L. L. Lopes (1987), points out the fact that, as far as people are concerned, one of the mentioned emotions does not necessarily dominate over the other (fear over hope, or hope over fear), thus considering people to be "cautiously optimistic". Under the influence of fear, investors overestimate the likelihood of the worst outcomes, whereas under the influence of hope, they overestimate the likelihood of the best outcomes. Therefore, under the influence of fear, investors buy risk-free securities in order to achieve security and avoid poverty, whereas under the influence of hope, they invest in highly risky assets so as to maximize their wealth.

Accordingly, one of the significant implications of SP/A theory, one of the major pillars of the BPT, assumes that, while creating their investment portfolios, investors tend to combine very secure and very risky assets, thereby creating the key to understanding the investment portfolio as a collection of different subportfolios, i.e. a layered investment pyramid.

According to H. Shefrin (2008), SP/A theory holds many advantages compared to prospect theory and is a more solid basis for the BPT development, because it better explains the way how individuals make decisions and the existence of a mix of riskfree securities and highly-risky securities in a behavioral portfolio. Eight years later, H. Shefrin (2016) points out the fact that both theories, prospect theory (emphasizing cognition) and SP/A theory (emphasizing emotions) are equally important, as cognition and emotions are intertwined. In other words, the aforementioned theories can be considered as complementary, i.e. being the two parts of the same story about the role of psychology in the decisionmaking process.

\section{BEHAVIORAL PORTFOLIO THEORY AS A MEANS OF MODERN PORTFOLIO THEORY ENHANCEMENT}

Based on the above-presented theories, namely prospect theory and SP/A theory, the BPT considers that investors are risk-averse and risk-seeking at the same time, i.e. they purchase both insurance policies and state lottery tickets. In contrast to the BPT, the alternative MPT assumes that investors are riskaverse, which is precisely why they are unwilling to invest money in buying state lottery tickets (Das, Markowitz, Scheid \& Statman, 2011). If, based on the MPT concept, a rational investor is given a choice between buying lottery tickets and putting money into a diversified portfolio, he/she will opt for a diversified portfolio, since it is characterized by a lower standard deviation of the return as a measure of risk. In addition, the expected return on a state lottery ticket is negative, while the expected return of a diversified portfolio is positive.

An investor who, under the above-described circumstances, chooses to invest money in a diversified portfolio is clearly risk-averse. However, according to behavioral finance, the same investor is considered to be risk-seeking if his/her objective is to earn an amount of $€ 100,000,000.00$ in a shortterm period by investing $€ 1.00$. In terms of the BPT, risk is not measured by a standard deviation of the return; it is rather measured by a shortfall probability, i.e. the probability that such a return will be below a certain target amount, the mean shortfall, or their difference. If the investor chooses to invest money in a diversified portfolio, the risk that the return will be below the target amount is higher than in the case of buying a state lottery ticket, which is why this person is considered to be a risk-seeking investor. 
Therefore, it can be concluded that certain portfolios considered as low-risk portfolios in terms of the standard finance and the MPT methodologies can be assessed as high-risk portfolios based on behavioral finance and the BPT due to a high probability of failure in achieving the set goal. Likewise, portfolios assessed as high-risk portfolios according to standard finance and the MPT methodologies can be considered as low-risk in terms of behavioral finance and the BPT due to a low probability of failure in the achievement of the set goal (Statman 2014).

The main feature of the BPT is the assumption that investors do not view their portfolios as a whole, as is proposed by the MPT, but rather as separate mental account layers, where each mental account layer is associated with a particular goal and a certain attitude toward risk. Therefore, according to the BPT, investors' goals and attitudes towards risk differ across layers (Statman, 2008). According to the BPT concept, investors consider their portfolio as a collection of sub-portfolios, each of which is optimal for a given mental account (Pfiffelmann et al, 2016).

A BPT portfolio resembles a layered pyramid, where, starting from the base layer as the lowaspiration level, the investor's aspirations are becoming more ambitious with each successive level, as well as risk tolerance. That is to say, at the base layer of the pyramid, investors buy insurance policies and government bonds; at the middle layer of the pyramid, they purchase shares of several companies and junk bonds, whereas at the topmost layer, they opt for shares of a single company and state lottery tickets. According to H. Shefrin (2015), investors create layered portfolios in order to protect themselves against risks, simultaneously creating an opportunity to earn profit. One way to do this is to invest in put options at the lower layers of a mental account (downside protection) and to concurrently invest in call options at the upper layers of a mental account, i.e. an upside potential mental account (Das \& Statman, 2013).

The BPT emphasizes investors' goals associated with respective specific mental account layers (the goalbased approach). Normal people, i.e. investors, want more than portfolios on the mean-variance efficient frontier. Their ultimate goal is to create a portfolio which will satisfy the goals defined at each layer of the portfolio pyramid (Das et al, 2011).

In accordance with the previously stated points, $\mathrm{M}$. Statman $(2014,68)$ points out the fact that normal investors start the process of constructing behavioral portfolios by dividing the basic portfolio into three mental accounts as layers in the portfolio pyramid. The first mental account (the bottom layer of the pyramid) is designed so as to provide protection from poverty; the second mental account (the middle layer of the pyramid) can be used for education purposes, and the third mental account (the topmost layer of the pyramid) is designed for the purpose of maximizing the investor's wealth. The first mental account is characterized by the investor's aversion to risk, due to which fact bonds make dominant assets at the lowest layer. The second mental account is characterized by a moderate level of risk tolerance, which is the reason why a combination of stocks and bonds prevails at the middle layer. Finally, the third mental account is characterized by the investor's willingness to take more risks, which is why stocks of a small number of companies, or even of a single company, account for dominant assets at the topmost layer. According to E. W. Rengifo et al, (2014), investors may have a "short" position in a particular security at one layer of the pyramid and yet maintain a "long" position in the same security at another layer of the pyramid.

The assertion of the BPT that investors demonstrate both risk-aversion and risk-seeking behavior, i.e. that they purchase both insurance policies and state lottery tickets, is explained by the aforementioned mental accounting. The investor's risk-seeking preference and striving to increase wealth are reflected in one mental account, whereas risk-aversion and playing safe in order to avoid poverty are reflected in another mental account. The advantage of mental accounting reflects in the fact that it is easier for an investor to determine his/her level of risk tolerance for each mental account separately than do so for the portfolio as a whole, which requires adding up all abstract mental accounts in the investor's mind into an overall real-life account. 
This is how behavioral economists have managed to solve the Friedman-Savage puzzle (Friedman \& Savage, 1948), i.e. based on the mental accounting concept and its separate mental accounts (one account for prevention, i.e. playing safe, and another account for promotion, i.e. striving to achieve financial gains), they have given an answer to one of the most frequently cited puzzles in the finance literature: why do people buy both lottery tickets and insurance against losses?

In addition to quite different perceptions of risk, as well as the investment portfolio (a portfolio as a whole and as a collection of sub-portfolios), MPT rational investors and BPT normal investors are also guided by different sets of factors when constructing their desired portfolios. Rational investors construct portfolios guided by the ratio of the expected return and risk, whereas normal investors also consider their own desires, needs, biases, habits, preferences and emotions (Águila, 2009) and often employ heuristics, i.e. mental shortcuts, intuition, even guesswork. In other words, rational investors build their portfolios based on utilitarian benefits (the highest expected return and the lowest possible risk), whereas normal investors choose securities and other financial assets not only based on utilitarian, but also expressive and emotional benefits. The rational investor's goal is to maximize the utilitarian benefit reflected in wealth growth, i.e. maximizing returns for a given level of risk, whereas the normal investor seeks to maximize all the three dimensions of benefits.

According to M. Statman $(2014,66)$, utilitarian benefits answer the question of how the investor and his wallet benefit from a certain investment. Expressive benefits answer the question of what message a certain realized investment communicates to other people about the investor, i.e. what kind of impression the investor leaves on the people around him. Finally, emotional benefits answer the question of how the investor feels about himself/herself after a certain investment has been realized.

By purchasing shares of a socially responsible company caring about environmental protection, the normal investor realizes a utilitarian benefit in the form of increasing wealth, an expressive benefit, because it gives an impression of him as a socially responsible person, and emotional benefits by feeling satisfied and proud. In contrast to the normal investor, the rational investor can separate a reason from an emotion and can be guided by the sole goal of maximizing wealth. The rational investor is willing to invest in high-yield shares of a company producing alcoholic beverages, even though a member of his family might be fighting alcohol addiction.

According to M. Statman (2014), rational investors are able to separate their roles as investors from their roles as consumers. They invest in high-yield shares of companies producing weapons as investors, whereas they donate money for arms control campaigns as consumers. On the other hand, normal investors, even knowledgeable ones, fail to separate their roles as investors from their roles as consumers and do not invest in shares of the mentioned companies.

Since MPT and BPT investors are guided by different goals and different sets of factors when creating a desired portfolio, it is evident that the BPT's behavioral-wants frontier does not coincide with the MPT's mean-variance frontier; furthermore, the optimal BPT portfolio also differs from the optimal MPT portfolio (Figure 2).

Furthermore, MPT investors have only one efficient frontier to think of, whereas BPT investors have a number of efficient frontiers to consider - one for each mental account (Das et al, 2011). Therefore, rather than selecting a single and the most optimal portfolio, normal investors choose several optimal sub-portfolios - one per each layer of the portfolio pyramid. The optimal portfolio is constructed by combining optimal sub-portfolios. According to $\mathrm{H}$. Shefrin and M. Statman (2000, 128), an MPT optimal portfolio is a combination of the market portfolio and risk-free securities, whereas a BPT optimal portfolio resembles a mix of bonds and state lottery tickets because it actually represents a combination of such optimal sub-portfolios.

In terms of the MPT, the optimal portfolio varies from one investor to another, depending on the investor's attitude towards risk (the level of risk tolerance); 


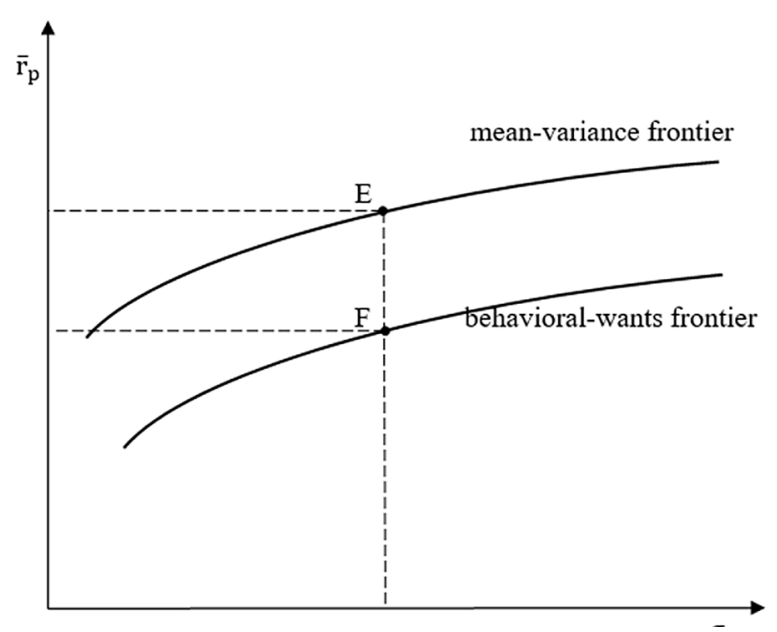

Figure 2 BPT and MPT efficient frontiers - a comparison

Source: Statman, 2017b, 44

however, in the BPT, the optimal portfolio varies across investors not only due to the different levels of risk tolerance, but also because of such investors' different desires, needs, biases, habits, preferences and emotions (social responsibility, patriotism, pride). C. T. Howard (2014) points out the fact that building an optimal MPT portfolio is emotionally difficult as it involves an exchange of emotions, heuristics and natural impulses and a focus on thoughtful analysis.

From the perspective of standard finance and the MPT, an optimal portfolio is a portfolio maximizing the investor's utilitarian benefits, i.e. the one producing the maximum expected return for a given preferred level of risk. On the other hand, from the perspective of behavioral finance and the BPT, an optimal portfolio is a portfolio which, at the given preferred level of risk, maximizes the overall benefits of an investment expressed as the sum of utilitarian, expressive and emotional benefits.

Figure 2 shows Portfolio E, which is the optimal portfolio of a rational investor who ignores expressive and emotional benefits, on the one hand, and Portfolio F, the optimal portfolio of a normal portfolio investor who equally considers all the three dimensions of benefits. Portfolio F is below Portfolio E, because the desire for the realization of expressive and emotional benefits usually results in a lower expected return for the same level of risk. Investors are willing to give up on a certain portion of such an expected return in order to achieve expressive and emotional benefits; this is precisely the reason why the optimal portfolio, as well as the BPT's efficient frontier (the behavioralwants frontier), is positioned below that of the MPT (the mean-variance efficient frontier). Although Portfolio F does not produce the highest utilitarian benefits, it is optimal because it produces the highest overall benefits for investors considering all the three mentioned dimensions of benefits.

According to the proponents of behavioral finance, investors are willing to accept negative utilitarian benefits in exchange for immediate or potential expressive and emotional benefits. For example, they are willing to accept the negative expected return on a state lottery ticket in exchange for the hope of winning. In other words, they are willing to accept negative utilitarian benefits in exchange for immediate benefits in the form of the emotional excitement of gambling and potential expressive and emotional benefits in terms of the prestige and excitement that a lottery win might bring them.

In a similar fashion, a socially conscious investor is willing to give up on high-yielding stocks of companies engaged in providing gambling services, the production of alcohol, tobacco and weapons, in exchange for low-yielding stocks of socially responsible companies. Such willingness of investors is reflected in replacing utilitarian benefits with expressive and emotional benefits. Therefore, investors compensate for these reduced utilitarian benefits by expressive and emotional benefits. In the present case, the stocks of socially responsible and socially irresponsible companies are not considered as substitutes based on their equal levels of utilitarian benefits, but because they provide the same level of overall benefits. M. Statman (2017a) states that roses are not a substitute for chocolates by providing nutritional benefits, but they are rather a substitute for chocolates by providing expressive gratitude and emotional affection. 
Despite the fact that the BPT's and MPT's optimal portfolios differ from each other, the results of recent research (Das, Markowitz, Scheid \& Statman, 2010; Pfiffelmann et al, 2016) have shown that, eventually, the BPT and the MPT lead to selecting similar portfolios with more things in common than it was originally assumed. In a survey conducted by Pfiffelmann et al, (2016), the optimal BPT portfolio was on the MPT's efficient frontier in more than $70 \%$ of the cases. The research study was conducted without any limitations or restrictions: all the features (not only the selected BPT features) were taken into account and, in addition, the authors allowed for short sales and left out the assumption of the normal distribution of returns. However, the same research found that the BPT optimal portfolio always lies on the upper right part of the efficient frontier, which is characterized by a high level of risk. Therefore, in terms of standard finance, the average investor will select the BPT optimal portfolio despite the fact that it lies on the efficient frontier. The selection of such a portfolio requires a low level of risk aversion, which is not typical of the average traditional investor. More specifically, the selection of the most optimal BPT portfolio requires a level of risk aversion which is up to ten times as low as the investor's risk preferences in standard finance (Pfiffelmann et al, 2016).

By summarizing the above-stated points, a number of the differences between the MPT and the BPT that support the claim that the BPT evolved as an alternative and a great challenge to the MPT (Table 1) can be identified.

Bearing in mind the explained key features of both the BPT and the MPT, it can be concluded that, by incorporating psychological factors, the BPT "has gone one step further", thus upgrading and updating the MPT and standard finance. Specifically, the BPT has picked up where the MPT left off and filled the gaps in portfolio theory, thus making the circle complete. In addition to maximizing the utilitarian benefits, the BPT points to the investor's equally important goals, namely the maximization of expressive and emotional benefits. In this way, the BPT has brought portfolio theory closer to reality given the fact that, in real-life situations, investors are not solely guided by the goal of maximizing their personal wealth, but they also take into account social responsibility, conformism, and social acceptance. By introducing the mental accounting concept, the BPT has made a big step forward. Mental accounting allows the investor to accept several levels of risk tolerance instead of only one, as well as the plurality of investment goals. It has also provided an opportunity to build an optimal investment portfolio based on several optimal subportfolios ensuring the successful satisfaction of the investor's goals. The BPT reflects reality more realistically than the MPT does, due to the fact that it takes into consideration the true nature of people, their different desires, needs and preferences.

However, it is still too early and exaggerated to a certain extent to talk about the superiority of the BPT over the MPT, because both theories face the serious limitations identified and explained by G. Curtis (2004), which are as follows: by applying the MPT techniques, financial advisors propose portfolios to their clients, i.e. investors, which are optimal in terms of the relationship between a return and risk; however the likelihood that investors will follow the given advice is slim; on the other hand, by employing the BPT techniques, financial advisors propose the portfolios that resonate well with investors; however, such portfolios are not likely to be optimal in terms of the relationship between return and risk. As a financial advisor's client, the investor will be disappointed in both cases - in the first case, he/ she will be disappointed because of his/her failing to follow the financial expert's advice; in the second case, because of his/her having followed the given advice (Curtis, 2004, 19).

\section{THE BEHAVIORAL ASSET-PRICING MODEL AS AN ALTERNATIVE TO STANDARD FINANCIAL ASSET-PRICING MODELS}

Behavioral finance theory argues that it is essential to understand the psychology of market participants in order to be able to fully understand asset-pricing and the movement of asset prices (Fakhry, 2016, 458). The expected return on securities varies not only due 
Table 1 Summary of key differences between the MPT and BPT

\begin{tabular}{|c|c|}
\hline MPT & BPT \\
\hline $\begin{array}{l}\text { Investors are perfectly rational people, who can separate a } \\
\text { reason from emotions and who are guided by the sole aim } \\
\text { of maximizing their own wealth. }\end{array}$ & $\begin{array}{l}\text { Investors are normal, ordinary people, who, under the } \\
\text { influence of a cognitive bias and misleading emotions, do } \\
\text { not always make rational decisions and are not guided by } \\
\text { the sole aim of maximizing personal interests. }\end{array}$ \\
\hline Investors are solely characterized by risk aversion. & Investors are risk-seeking and risk-averse at the same time. \\
\hline $\begin{array}{l}\text { Risk is measured by a variance, i.e. a standard deviation of } \\
\text { returns. }\end{array}$ & $\begin{array}{l}\text { Risk is measured by a loss probability, i.e. failure to achieve } \\
\text { the set goal, mean shortfall, or as the product of losses. }\end{array}$ \\
\hline $\begin{array}{l}\text { Investors view a portfolio as a whole and do not apply the } \\
\text { mental accounting concept. }\end{array}$ & $\begin{array}{l}\text { Investors view a portfolio as a collection of sub-portfolios, } \\
\text { each of which is optimal for a particular mental account. }\end{array}$ \\
\hline $\begin{array}{l}\text { Investors have a single level of risk tolerance which is } \\
\text { applied to a portfolio as a whole. }\end{array}$ & $\begin{array}{l}\text { Investors have several levels of risk tolerance, one for each } \\
\text { mental account. }\end{array}$ \\
\hline $\begin{array}{l}\text { Investors have one overall goal (maximizing returns at a } \\
\text { preferred level of risk) which is applied to a portfolio as a } \\
\text { whole. }\end{array}$ & $\begin{array}{l}\text { Investors have several goals (avoiding poverty, education, } \\
\text { increasing wealth), one goal per each mental account. }\end{array}$ \\
\hline $\begin{array}{l}\text { Investors construct their portfolios guided solely by the } \\
\text { expected return to risk ratio. }\end{array}$ & $\begin{array}{l}\text { Investors construct their portfolios guided by the } \\
\text { expected return to risk ratio, as well as their wishes, needs, } \\
\text { habits and emotions. }\end{array}$ \\
\hline Investors have to deal with only one efficient frontier. & $\begin{array}{l}\text { Investors have to deal with several efficient frontiers - one } \\
\text { frontier per each mental account. }\end{array}$ \\
\hline Investors select a single optimal portfolio. & $\begin{array}{l}\text { Investors select several optimal sub-portfolios - one per } \\
\text { each level of the portfolio pyramid. }\end{array}$ \\
\hline $\begin{array}{l}\text { The optimal portfolio is a combination of a market } \\
\text { portfolio and risk-free assets. }\end{array}$ & $\begin{array}{l}\text { The optimal portfolio is constructed by integrating optimal } \\
\text { sub-portfolios and it resembles a mix of stocks and state } \\
\text { lottery tickets. }\end{array}$ \\
\hline $\begin{array}{l}\text { The optimal portfolio is a portfolio maximizing the } \\
\text { investor's utilitarian benefits. }\end{array}$ & $\begin{array}{l}\text { The optimal portfolio is a portfolio maximizing the } \\
\text { investor's overall benefits expressed as a sum of utilitarian, } \\
\text { expressive and emotional benefits. }\end{array}$ \\
\hline $\begin{array}{l}\text { The optimal portfolio varies across investors, depending } \\
\text { on their level of risk tolerance. }\end{array}$ & $\begin{array}{l}\text { The optimal portfolio varies across investors not only due } \\
\text { to different levels of risk tolerance, but also because of } \\
\text { their different desires, needs, biases, habits, preferences } \\
\text { and emotions. }\end{array}$ \\
\hline
\end{tabular}

Source: Author

to differences in the risk level that various securities carry with themselves. In addition to risks, there are numerous psychological factors which influence the investor's choice, the price of securities and, ultimately, the expected return (Hirshleifer, 2001). The psychological factors that support the selection of a particular security do increase the price of this security through increased demand and also reduce its return; vice versa, too, the psychological factors that do not support the choice of a certain security lower the price of this security through reduced demand while increasing its return.
Based on the aforementioned facts, $\mathrm{H}$. Shefrin and M. Statman (1994) developed the BAPM model as an alternative to the following standard financial asset-pricing models: the capital asset-pricing model - CAPM, the Fama-French three-factor model, the Carhart four-factor model, and arbitrage pricing theory - APT.

Based on CAPM, the beta coefficient (as a measure of systemic risk) is the only factor that determines the rate of the expected return. In addition to the beta coefficient, the Fama-French three-factor model introduces equity market capitalization and the ratio 
of book value to market value (the $\mathrm{B} / \mathrm{M}$ ratio) as the main factors of risk, as well as the indicators of future returns. The Carhart four-factor model is an extension of the Fama-French three-factor model, including the momentum factor (inertia) as the fourth factor while, according to the APT model, the rate of the expected return depends on a number of factors; however, the model does not specify the factors in question.

With an increasing number of factors, the complexity of the model also increases, thus robbing such models of their elegance. However, as M. Statman (2008) points out, investors, portfolio managers and financial professionals do not need elegant models; they need the models that describe real people in real markets, and these are behavioral finance models. Behavioral finance offers the BAPM model, which is no less elegant than standard finance models; however, it is much closer to reality.

The creators of the BAPM model, H. Shefrin and M. Statman (1994), point out the fact that fundamental standard finance theories - the CAPM model and the Efficient Market Hypothesis (EMH), also referred to as the twin theories - can only be applied to the markets composed of rational investors and information traders. However, such markets do not exist in the real world and, hence, do not reflect reality, but an idealized concept. In real life, real markets are composed not only of information traders, but also of noise traders, who are prone to making cognitive errors and irrational decisions. Irrational optimists or pessimists make the market inefficient and cancel the validity of the CAPM model due to their actions. According to M. M. Pompian (2006, 272), in most cases, investors are unaware of their predisposition to make wrong moves and act irrationally.

In contrast to traditional economists' claim that rational investors succeed in annulling the influence of irrational investors by rationally making buying transactions, thereby cancelling the selling transactions of irrational investors, and vice versa, behavioral economists clearly stress the limitations of arbitration. In other words, while standard finance theory suggests that the impact of the irrational behavior of market participants is irrelevant because market forces will always act to bring prices back to rational levels (Lo, 2005, 21), behavioral finance theory emphasizes the influence of irrational behavior caused by the effects of various psychological factors.

By successfully incorporating psychological factors in the process of financial asset-pricing, the BAPM model has made "a step forward" compared to standard finance models (Chandra \& Thenmozhi, 2017). According to D. Hirshleifer (2001), the asset-pricing models based on psychology are an opportunity to "catch up with reality". M. Statman (2014) warns that researchers are too busy finding new factors and determining statistically significant associations between these factors and the realized return to pause and think about theoretical rationales for these associations. Today, the number of the identified factors associated with stock returns continues to grow in a statistically significant manner. However, M. Statman (2014) points out the fact that theoretical rationales for such factors are as important as statistical significance. The statistical significance of associations between the factors and actual returns may be strong even when such theoretical rationales are weak, and vice versa. Theoretical rationales are of crucial importance, because their absence practically cancels statistical significance .

In addition to attributing different levels of importance to incompletely informed investors ("noise traders") and their irrational decisions, another important difference between the standard financial assetpricing models and the BAPM model reflects in the fact that standard models price assets based on their utilitarian benefits, whereas the BAPM model prices assets based not only on their utilitarian benefits, but also on expressive and emotional ones. Therefore, in line with the BAPM model, assets are worthy because they bring utilitarian benefits (low risk, high returns), as well as expressive (social responsibility, patriotism) and emotional (satisfaction, pride, excitement caused by trading) benefits.

We should also keep in mind the fact that the financial asset-pricing process is also affected by cognitive errors and misleading emotions (e.g. when investors differently estimate a company's stock 
value due to the information on the company size), in addition to utilitarian, expressive and emotional benefits. If a financial analyst communicates to investors that a company is a large business, this will evoke positive emotions; on the other hand, if a financial advisor informs investors that the company they are interested in is a small business, negative emotions will come to surface regardless of the fact that, according to the research findings, the shares of the companies with low market capitalization usually generate higher returns.

The conclusion is that, based on the BAPM model, the expected return on assets is determined by utilitarian benefits, expressive benefits, emotional benefits, as well as cognitive errors and misleading emotions. For example, the expected return of a company's stocks depends on risk, liquidity, social responsibility, prestige, excitement, as well as cognitive errors and misleading emotions.

A preference for stocks of a certain company based on expressive and emotional benefits means greater demand, higher prices and a smaller expected return, i.e. a lower utilitarian benefit. In this respect, it is not surprising that, for example, the shares of socially responsible companies have a lower expected return than the shares of companies in the military, alcohol and tobacco industries (Hong \& Kacperczyk, 2009; Statman, 2014). To sum up, higher expressive and emotional benefits result in lower utilitarian benefits. Therefore, as is explained above, the behavioral finance optimal portfolio as a rule earns a lower expected return for the same level of risk than the standard finance optimal portfolio.

The differences in the pricing of real assets are explained by the differences in terms of utilitarian, expressive and emotional benefits. Mercedes and Dacia provide the same level of utilitarian benefits in terms of the transport of passengers from one place to another; however, Mercedes provides higher expressive benefits in the form of luxury, the style and a refined taste, as well as greater emotional benefits in the form of higher satisfaction and pride. Higher expressive and emotional benefits result in a higher price which consumers are willing to pay when buying a Mercedes. In this case, the expected price of a car is the function of its usefulness as a means of transportation and the fact that it reflects luxury, the style, a refined taste, pleasure, pride, cognitive errors and misleading emotions.

M. Statman (2017a) points out the fact that investment asset-pricing models can be compared with pricing models for meals, cars, films and every other product and service. The value of a dinner in a restaurant reflects in the fact that it brings not only utilitarian benefits (a nutritional value), but also expressive (prestige) and emotional (satisfaction, a good taste, aesthetics) ones. In this regard, it is no wonder that a restaurant meal is more expensive than a supermarket meal, although both meals have an equal nutritional value. Therefore, in terms of pricing products and services, cognitive and emotional errors must be taken into consideration; for example, consumers will perceive the same wine in different ways, depending on the bottle's price tag, i.e. the information on its price. A higher price tag on a wine bottle creates an illusion of a better quality and a better taste, and evokes a feeling of a greater pleasure; however, the same wine with a lower price tag evokes quite different reactions, i.e. an opposite sentiment. In a similar fashion, a consumer will perceive exactly the same pair of sunglasses differently, again depending on the price tag. He/she will perceive a more expensive pair as more quality eyewear than the pair with a lower price tag.

It is important to emphasize the fact that standard finance completely ignores the effect of affect in the process of financial asset-pricing, whereas the BAPM model duly recognizes its importance. According to P. Slovic, M. L. Finucane, E. Peters and D. G. MacGregor (2007), an affect is an inevitable component of human judgment and decision-making. An affect is a short-lasting positive or negative feeling or emotion that accelerates the decisionmaking process. The very mention of certain car, mobile phone and watch brands evokes feelings of desirability or undesirability in consumers. There is a similar situation in the case of company shares. Shares of socially and environmentally responsible companies are associated with producing a positive 
affect and are a preferred choice in relation to shares of companies operating in the alcohol, military and tobacco industries.

A positive affect depresses the perception of risk in investors' eyes, whereas a negative affect intensifies the perception of overall risk. A negative affect is the source of high subjective risk, whereas low subjective risk is associated with a positive affect. In contrast to standard finance, which does not recognize the concept of subjective risk, behavioral finance includes the category of the total risk defined as objective risk plus the level of subjective risk. Thus, standard finance views risk as an objective category, whereas, according to N. Linciano (2010), behavioral finance argues that risk and uncertainty are not only mathematical and statistical concepts, but also psychological constructs. Furthermore, standard finance emphasizes the quantitative aspects of risk and assumes a positive correlation between return and risk, whereas behavioral finance focuses on the qualitative features of risk and seeks to explain the occurrence of a negative correlation between return and risk (Ricciardi, 2008).

Behavioral economists explain a possible negative correlation between return and risk as a result of the effects of subjective risk. If objective risk is relatively low, the expected return can be high, due to a negative affect, i.e. due to high subjective risk. A negative affect increases the level of risk in the eyes of investors, thereby reducing their demand for assets regardless of the fact that the price of such assets is going down and their expected return is going up. Again, if objective risk is relatively high, the expected return might be low as a result of a positive affect, i.e. low subjective risk. A positive affect reduces the level of risk in the eyes of investors and increases their preference for the assets whose price is going up, while the expected return is going down.

Therefore, according to the BAPM model, affects play an important role in the pricing of financial assets as investors prefer assets with a positive affect and avoid assets with a negative affect. When investors have positive feelings, i.e. a positive affect, they perceive financial assets as highly beneficial and risk-free, whereas, in the case of a negative affect, the same assets are perceived as offering few benefits and being risky (Linciano, 2010). Positive preferences boost asset prices, while negative preferences adversely affect the price of assets.

Another important factor affecting the process of financial decision-making and financial asset-pricing refers to mental schemas. Mental schemas are the subjective experiences that exist at the unconscious level and may affect the process of perception and reasoning. The smell of fresh donuts evoking the happy memories of childhood and the warmth of the family home triggers the activation of the mental schema that subconsciously drives us to buy the product, even if we are not hungry. In a similar fashion, due to the operation of mental schemas, investors often opt to purchase the shares of the local companies where their parents used to work or the land that was once owned by their family. In this way, the operation of mental schemas increases demand for the mentioned assets, thereby increasing their price.

The formation of mental schemas can also result in making irrational decisions. While house hunting, when faced with the choice between two houses identical in the square footage, the backyard size and the location, a prospective houseowner will opt for the house that reminds him/her of his/her family house and will be willing to pay a significantly higher amount of money for that house. Such a decision and other similar irrational decisions made by such investors are the reasons why the prices of real and financial assets do not reflect the real value of such assets.

By summarizing the abovementioned facts, numerous differences between the BAPM model and the standard financial asset-pricing models can be identified. This also supports the position that the BAPM model has been developed as an alternative and a great challenge to standard financial assetpricing models (Table 2).

With this in mind, and having presented the main characteristics of the standard asset-pricing models and BAPM as well, it is only logical to conclude that, by taking into account the psychological factors, BAPM 
Table 2 Summary of key differences between standard finance asset pricing models and BAPM

\begin{tabular}{l|l}
\hline Standard finance asset pricing models & BAPM model \\
\hline $\begin{array}{l}\text { Expected return on assets varies due to different risk } \\
\text { levels. }\end{array}$ & $\begin{array}{l}\text { Expected return on assets varies not only due to different } \\
\text { risk levels, but also numerous psychological factors. } \\
\text { The impact of the irrational behavior of market } \\
\text { participants is irrelevant, since rational investors succeed } \\
\text { in canceling the influence of irrational investors. }\end{array}$ \\
$\begin{array}{l}\text { Assets are priced based on their utilitarian benefits. } \\
\text { participants is important, since rational investors fail to } \\
\text { cancel the influence of irrational investors, which supports } \\
\text { the position on arbitration limitations. }\end{array}$ \\
$\begin{array}{l}\text { Assets are priced not only based on their utilitarian } \\
\text { benefits, but also based on expressive and emotional } \\
\text { Asset prices are not affected by cognitive errors and } \\
\text { misleading emotions. }\end{array}$ \\
$\begin{array}{l}\text { Affects have no impact on the pricing of financial assets. } \\
\text { Asset prices are affected by cognitive errors and } \\
\text { misleading emotions. }\end{array}$ \\
$\begin{array}{l}\text { assets. } \\
\text { Risk is an objects strongly affect the pricing of financial assets. } \\
\text { affects, therefore it is not psychological, but exclusively } \\
\text { mathematical and statistical concept. }\end{array}$ \\
\hline
\end{tabular}

Source: Author

has succeeded in matching theoretical asset-pricing to real life situations. This important step forward was made due to the fact that this psychology-based assetpricing model recognized the limits of arbitration, thus emphasizing the significance of the impact of market participants' irrational behavior. BAPM has incorporated the utilitarian benefits (the foundation stone of standard finance) and added expressive and emotional benefits as the important determinants of the asset-pricing process; therefore, this model is rightly recognized as an upgrade to the standard financial asset-pricing models. Specifically, the BAPM model has not only included risk as an important building block of standard finance, but it has also included many psychological elements, such as a positive and a negative affect and mental schemas, thereby improving the standard financial assetpricing models.

The above-stated facts are supportive of the conclusion on the superiority of BAPM over standard financial asset-pricing models. However, as pointed out by N. Barberis (2018), it is still too early to make any definite conclusions in this respect, because the behavioral approach to asset-pricing that rests upon psychological factors is still relatively young compared to the traditional approach that emerged three decades ago.

\section{CONCLUSION}

The summary of the key differences between the MPT and the BPT, i.e. between the standard financial assetpricing models and BAPM, unambiguously confirm the fact that the BPT and BAPM have been developed as an alternative and a great challenge to standard finance theory. Given the fact that both the BPT and BAPM include and better understand the impact of psychological factors, these models fill the gaps in portfolio theory and asset-pricing models, thus making the circle complete. A better understanding of psychological factors allows investors to overcome cognitive errors and resist the impact of misleading emotions. This understanding of psychological elements, their role and significance, indeed improves 
the efficiency of portfolio management. Furthermore, a better understanding of the impact of psychological factors and the investment decision-making process in general implies a better understanding of financial asset-pricing methods and, therefore, a more efficient allocation of assets.

In contrast to the standard finance theory and the respective models that advise investors how to make investment decisions (the normative approach), the BPT and BAPM seek to explain how individual investors actually make decisions in practice (the positive approach). In addition, unlike the theories and standard finance models which, because of the application of too restrictive assumptions and strict scientific rules fail to explain the complex financial reality, the BPT and BAPM incorporate the concept of mental accounting, bounded rationality, expressive and emotional benefits, as well as the concept of arbitration limitations, thus managing to bring financial theory closer to reality and supplement standard finance theory, which confirms the initial hypothesis stated herein. Nevertheless, it is still too early and exaggerated to a certain extent to talk about the superiority of the BPT and BAPM over the MPT and standard asset-pricing models since both the behavioral and standard approaches face significant limitations. The above-mentioned conclusions are the key findings, as well as the outcome, of the research study and as such, they are compatible with the conclusions reached by G. Curtis (2004) and N. Barberis (2018).

The contribution of this paper to theory reflects in the fact that it elaborates the first qualitative research of the BPT and BAPM in the domestic literature, thus contributing to a better understanding of these relatively young theoretical frameworks. Furthermore, the theoretical contribution of the paper reflects in the identification and summary of the key differences between the BPT and the MPT, i.e. between BAPM and standard financial asset-pricing models.

In practical terms, a better understanding and application of the BPT and BAPM can be of a great benefit to investors, portfolio managers, financial experts and other participants in the market in terms of improving investment activities, making portfolio management more efficient and performing more accurate asset-pricing and an efficient allocation of assets.

The main limitation of the paper originates from the absence of the original empirical research study and the empirical verification of the initial hypothesis. In addition, an empirical analysis aimed at comparing the postulates of and benefits from the application of the BPT and BAPM with those of standard finance theory and models was not carried out. The Carrying out an appropriate empirical research study calls for a comprehensive quantitative analysis going beyond the content of this research study and also constitutes a recommendation for future research in this field.

For example, future research in this field could explore the possible optimal solution that would reconcile the conflicting viewpoints of traditional and behavioral economists, which could be achieved by applying an eclectic approach in order to create a synergy between the available knowledge and combine the best elements of behavioral and standard finance.

\section{REFERENCES}

Águila, N. D. (2009). Behavioral Finance: Learning from market anomalies and psychological factors. Revista de Instituciones, Ideas y Mercados, 50, 47-104.

Bakar, S., \& Yi, A. N. C. (2016). The Impact of psychological factors on investors' decision making in Malaysian stock market: A case of klang valley and pahang. Procedia Economics and Finance, 35, 319-328. doi.org/10.1016/S22125671(16)00040-X

Barberis, N. (2018). Psychology-based models of asset prices and trading volume. NBER Working Paper No. 24723. National Bureau of Economic Research. doi.org/10.2139/ ssrn.3177616

Blanco, F. (2017). Cognitive bias. In J. Vonk \& T. Shackelford (Eds.). Encyclopedia of Animal Cognition and Behavior (pp. 1-6). Cham: Springer. doi.org/10.1007/978-3-319-47829-6_1244-1 
Brajković, A., \& Peša, A. R. (2015). Bihevioralne financije i teorija "Crnog labuda“. Oeconomica Jadertina, 1, 65-93.

Chandra, A., \& Thenmozhi, M. (2017). Behavioural asset pricing: Review and synthesis. Journal of Interdisciplinary Economics, 29(1), 1-31. doi.org/10.1177/0260107916670559

Cupic, M. (2015). Risk management and corporate value. Economic Horizons, 17(3), 215-228.

Curtis, G. (2004). Modern portfolio theory and behavioral finance. The Journal of Wealth Management, 7(2), 16-22. doi. org/10.3905/jwm.2004.434562

Das, S., Markowitz, H., Scheid, J., \& Statman, M. (2010). Portfolio optimization with mental accounts. Journal of Financial and Quantitative Analysis, 45(2), 311-334. doi. org/10.1017/S0022109010000141

Das, S., Markowitz, H., Scheid, J., \& Statman, M. (2011). Portfolios for investors who want to reach their goals while staying on the mean-variance efficient frontier. The Journal of Wealth Management, 14(2), 25-31. doi.org/10.3905/ jwm.2011.14.2.025

Das, S., \& Statman, M. (2013). Options and structured products in behavioral portfolios. Journal of Economic Dynamics and Control, 37(1), 137-153. doi.org/10.1016/j.jedc.2012.07.004

De Bondt, W. F. M., Muradoglu, Y. G., Shefrin, H., \& Staikouras, S. K. (2008). Behavioral finance: Quo vadis? Journal of Applied Finance, 18(2), 7-21.

De Bondt, W. F. M., Mayoral, R. M., \& Vallelado, E. (2013). Behavioral decision-making in finance: An overview and assessment of selected research. Spanish Journal of Finance and Accounting, 42(157), 99-118. doi.org/10.1080/02102412.20 13.10779742

Fakhry, B. (2016). A literature review of behavioural finance. Journal of Economics Library, 3(3), 458-465. doi.org/10.1453/jel. v3i3.929

Friedman, M., \& Savage, L. J. (1948). The utility analysis of choices involving risk. The Journal of Political Economy, 56(4), 279-304. doi.org/10.1086/256692

Hirshleifer, D. (2001). Investor psychology and asset pricing. The Journal of Finance, 56(4), 1533-1597. doi.org/10.1111/00221082.00379

Hong, H., \& Kacperczyk, M. (2009). The price of sin: The effects of social norms on markets. Journal of Financial Economics, 93(1), 15-36. doi.org/10.1016/j.jfineco.2008.09.001
Howard, C. T. (2014). Behavioral portfolio management. Journal of Behavioral Finance \& Economics, Forthcoming. Retrieved June 30, 2019 from https://papers.ssrn.com/sol3/ papers.cfm?abstract_id=2210032

Kahneman, D., \& Tversky, A. (1979). Prospect theory: An analysis of decision under risk. Econometrica, 47(2), 263-292.

Linciano, N. (2010). Cognitive biases and instability of preferences in the portfolio choices of retail investors. Working Paper No. 66, Commissione Nazionale per le Societa e la Borsa. doi.org/10.2139/ssrn.1898560

Lo, A. W. (2005). Reconciling efficient markets with behavioral finance: The adaptive markets hypothesis. The Journal of Investment Consulting, 7(2), 21-44.

Lopes, L. L. (1987). Between hope and fear: The psychology of risk. Advances in Experimental Social Psychology, 20, 255-295. doi.org/10.1016/S0065-2601(08)60416-5

Lopes, L. L., \& Oden, G. C. (1999). The role of aspiration level in risk choice: A comparison of cumulative prospect theory and SP/A theory. Journal of Mathematical Psychology, 43, 286313. doi.org/10.1006/jmps.1999.1259

Muradoglu, G., \& Harvey, N. (2012). Behavioral finance: The role of psychological factors in financial decisions. Review of Behavioral Finance, 4(2), 68-80. doi. org/10.1108/19405971211284862

Pfiffelmann, M., Roger, T., \& Bourachnikova, O. (2016). When behavioral portfolio theory meets Markowitz theory. Economic Modelling, 53, 419-435. doi.org/10.1016/j. econmod.2015.10.041

Pompian, M. M. (2006). Behavioral Finance and Wealth Management. Hoboken, New Jersey: Wiley \& Sons, Inc.

Rengifo, E. W., Trendafilov, R., \& Trifan, E. (2014). Behavioral Portfolio Theory and Investment Management. In $\mathrm{H}$. K. Baker \& V. Ricciardi (Eds.). Investor Behavior - The Psychology of Financial Planning and Investing (pp. 421438). Hoboken, New Jersey: John Wiley \& Sons, Inc. doi. org/10.1002/9781118813454.ch23

Ricciardi, V. (2008). Risk: Traditional finance versus behavioral finance. In F. J. Fabozzi, (Ed.). Valuation, Financial Modeling, and Quantitative Tools (pp. 11-38). John Wiley \& Sons.

Shefrin, H. (2008). A Behavioral Approach to Asset Pricing. USA: Elsevier Inc. 
Shefrin, H. (2015). The behavioral paradigm shift. Revista de Administração de Empresas, 55(1), 95-98. doi.org/10.1590/ S0034-759020150109

Shefrin, H. (2016). Behavioral Risk Management: Managing the Psychology That Drives Decisions and Influences Operational Risk. USA: Palgrave Macmillan.

Shefrin, H., \& Statman, M. (1994). Behavioral capital asset pricing theory. Journal of Financial and Quantitative Analysis, 29(3), 323-349. doi.org/10.2307/2331334

Shefrin, H., \& Statman, M. (2000). Behavioral portfolio theory. Journal of Financial and Quantitative Analysis, 35(2), 127-151. doi.org/10.2307/2676187

Simon, H. A. (1955). A behavioral model of rational choice. The Quarterly Journal of Economics, 69(1), 99-118. doi. org $/ 10.2307 / 1884852$

Slovic, P., Finucane, M. L., Peters, E., \& MacGregor, D. G. (2007). The affect heuristic. European Journal of Operational Research, 177, 1333-1352. doi.org/10.1016/j.ejor.2005.04.006
Statman, M. (2008). What is behavioral finance? In F. J. Fabozzi (Ed.). Handbook of Finance (pp. 79-84). Hoboken, NJ: John Wiley \& Sons, Inc. doi.org/10.1002/9780470404324.hof002009

Statman, M. (2014). Behavioral finance: Finance with normal people. Borsa Istanbul Review, 14, 65-73. doi.org/10.1016/j. bir.2014.03.001

Statman, M. (2017a). Behavioral asset pricing: Asset pricing for normal people. The Journal of Portfolio Management, 44(1), 5-9. doi.org/10.3905/jpm.2017.44.1.005

Statman, M. (2017b). Behavioral portfolios: Portfolios for normal people. Excerpt from Finance for Normal People: How Investors and Markets Behave, Oxford University Press.

Todorović, M. (2011). Psihologija i finansijski menadžment bihevioralne korporativne finansije. Ekonomika preduzeća, 59(3/4), 275-287.

Received on $28^{\text {th }}$ October 2019, after revision, accepted for publication on $23^{\text {rd }}$ December 2019 Published online on $25^{\text {th }}$ December 2019

Miljan Lekovic is an Assistant Professor at the Faculty of Hotel Management and Tourism in Vrnjačka Banja, University of Kragujevac, where he teaches Principles of Economics and National Economy. He received his doctorate from the Faculty of Economics, University of Kragujevac. His research interest is focused on the financial economics. 


\title{
BIHEJVIORALNA PORTFOLIO TEORIJA I BIHEJVIORALNI MODEL VREDNOVANJA AKTIVE KAO ALTERNATIVA UČENJU STANDARDNIH FINANSIJA
}

\author{
Miljan Leković* \\ Fakultet za hotelijerstvo i turizam u Vrnjačkoj Banji Univerziteta u Kragujevcu
}

\begin{abstract}
Udaljavanjem standardne finansijske teorije od prakse stvorio se prostor za pojavu novih teorija i novih modela vrednovanja aktive. Povoljnu priliku za popularizaciju svojih ideja, iskoristili su bihejvioralni ekonomisti koji su razvili teoriju bihejvioralnih finansija nasuprot teoriji standardnih finansija, bihejvioralnu portfolio teoriju nasuprot savremenoj portfolio teoriji i bihejvioralni model vrednovanja aktive nasuprot standardnim modelima vrednovanja finansijske aktive. Cilj rada je da se izvrši predstavljanje ovih novih teorijskih okvira, s obzirom na odsustvo domaćih istraživanja na temu bihejvioralne portfolio teorije i bihejvioralnog modela vrednovanja aktive. Namera je da se, kroz uporednu analizu sa teorijama i modelima standardnih finansija, prikažu ključne odlike bihejvioralne portfolio teorije i bihejvioralnog modela vrednovanja aktive. Primenom kvalitativne metodologije istraživanja, zaključeno je da bihejvioralna portfolio teorija i bihejvioralni model vrednovanja aktive inkorporiranjem psiholoških faktora dopunjuju učenje standardnih finansija i približavaju finansijsku teoriju stvarnosti, ali i da je još uvek rano govoriti o superiornosti ovih novih teorijskih okvira u odnosu na savremenu portfolio teoriju i standardne modele vrednovanja finansijske aktive, što predstavlja i glavni rezultat istraživanja.
\end{abstract}

Ključne reči: bihejvioralne finansije, psihološki faktori, mentalni račun, utilitaristička korist, ekspresivna korist, emocionalna korist

JEL Classification: G40, G41

\section{UVOD}

Bihejvioralne finansije predstavljaju novi pristup području finansija (Brajković \& Peša, 2015), koji izučava ulogu, značaj i uticaj psiholoških faktora na ponašanje i odlučivanje investitora, portfolio

* Korespondencija: M. Leković, Fakultet za hotelijerstvo i turizam u Vrnjačkoj Banji, Univerzitet u Kragujevcu, Vojvođanska 5A, 36210 Vrnjačka Banja, Republika Srbija; e-mail:m.lekovic@kg.ac.rs menadžera, finansijskih stručnjaka i ostalih učesnika na tržištu (Muradoglu \& Harvey, 2012; Bakar \& Yi, 2016). Za razliku od standardnih finansija koje polaze od koncepta savršene racionalnosti, bihejvioralne finansije se zasnivaju na mnogo realnijem konceptu ograničene racionalnosti, koji je u ekonomiju uveo $\mathrm{H}$. A. Simon (1955).

$\mathrm{U}$ osnovi bihejvioralnih finansija nalazi se tvrdnja da investitori poseduju kognitivne predrasude, 
koje predstavljaju nesavršenu percepciju stvarnosti (Blanco, 2017), koja rezultira sistemskim greškama u rasuđivanju i iracionalnim odlukama. Bihejvioralne finansije nastoje da razumeju investitore, njihovo ponašanje i odlučivanje. $S$ tim $u$ vezi, bihejvioralne finansije pretpostavljaju „normalnog“ investitora, tj. običnog čoveka koji nije uvek savršeno informisan i koji, pod uticajem kognitivnih pristrasnosti i obmanjujućih emocija, ne donosi uvek racionalne odluke. Prema W. F. M. De Bondt-u, Y. G. Muradoglu-u, H. Shefrin-u i S. K. Staikouras-u (2008), ukoliko akademska javnost želi da razume finansijske institucije i učesnike na finansijskom tržištu i ukoliko kreatori ekonomske politike i ekonomski agenti žele da donose mudre odluke, oni moraju da uzmu u obzir pravu prirodu ljudi, njihovu nesavršenost i ograničenu racionalnost.

Znanja iz oblasti bihejvioralnih finansija treba da pomognu donosiocima finansijskih odluka $u$ prepoznavanju i razumevanju sopstvenih grešaka, učenju na greškama i, što je najvažnije, njihovom izbegavanju u budućnosti (Muradoglu \& Harvey, 2012; De Bondt, Mayoral \& Vallelado, 2013). Bihejvioralni ekonomisti ističu da je finansijska teorija značajno unapređena sa pojavom bihejvioralnih finansija koje su „osvetlile“ područje finansijskog odlučivanja.

Imajući u vidu napred navedeno, predmet istraživanja u radu su bihejvioralna portfolio teorija (Behavioral Portfolio Theory - BPT) i bihejvioralni model vrednovanja aktive (Behavioral Asset Pricing Model BAPM), kao ključni sastavni elementi bihejvioralnih finansija. BPT i BAPM model, inkorporiranjem psiholoških elemenata i izbegavanjem suviše restriktivnih pretpostavki teorija i modela standardnih finansija, nastoje da objasne stvarni proces donošenja finansijskih odluka i vrednovanja finansijske aktive. Navedeni modeli su predmet istraživanja brojnih radova (Hirshleifer, 2001; Shefrin, 2008; Rengifo, Trendafilov \& Trifan, 2014; Statman, 2014; Pfiffelmann, Roger \& Bourachnikova, 2016; Chandra \& Thenmozhi, 2017; Statman, 2017a; Statman, 2017b; Barberis, 2018), ali ne i domaćih studija, što predstavlja motiv za sprovođenje odgovarajuće kvalitativne analize.
Cilj istraživanja je predstavljanje ovih relativno mladih, u domaćoj literaturi neistraženih, teorijskih okvira, koji su razvijeni kao alternativa standardnoj finansijskoj teoriji. Namera je da se domaća investiciona javnost bliže upozna sa znanjima iz oblasti bihejvioralnih finansija, koja mogu biti od velike koristi investitorima, portfolio menadžerima i ostalim tržišnim učesnicima. Svrha razmatranja BPT i BAPM modela je analiziranje novog pristupa i novog ugla posmatranja područja finansija koji nude bihejvioralne finansije, a koji obezbeđuje svojevrsnu zaokruženost finansijske teorije.

Očekivani ishod istraživanja je bolje razumevanje, na psihologiji zasnovanih, portfolio teorije, i modela vrednovanja finansijske aktive uz korisno identifikovanje i sumarni prikaz ključnih razlika između BPT i savremene portfolio teorije (Modern Portfolio Theory - MPT), odnosno, izmedu BAPM i standardnih modela vrednovanja aktive.

Shodno definisanom predmetu, postavljenom cilju i očekivanom ishodu istraživanja, definisana je sledeća polazna hipoteza:

$\mathrm{H}$ : Bihejvioralna portfolio teorija i bihejvioralni model vrednovanja aktive približavaju finansijsku teoriju stvarnosti, inkorporiranjem koncepta mentalnog računovodstva, ograničene racionalnosti, ekspresivne i emocionalne koristi i koncepta ograničenosti arbitraže.

U radu će biti primenjena kvalitativna metodologija istraživanja, koja će omogućiti da se, proučavanjem relevantne literature, izvrši teorijska verifikacija polazne hipoteze i formulišu validni zaključci o istraživanoj problematici.

Vodeći računa o opredeljenom predmetu, definisanom cilju i postavljenoj hipotezi, u radu će nakon uvodnih razmatranja, biti predstavljene teorija izgleda i Security-Potential/Aspiration teorija (SP/A), koje su poslužile kao osnov razvoja BPT. Potom će biti analizirane ključne odlike BPT, koje će radi lakšeg razumevanja biti prikazane kroz uporednu analizu sa odlikama MPT. Uslediće objašnjenje BAPM modela, koji je razvijen kao alternativa standardnim modelima vrednovanja finansijske aktive, uz apostrofiranje 
uticaja psiholoških faktora na investitorov izbor i vrednost aktive. U poslednjem, zaključnom delu rada sumiraće se stavovi o ispunjenosti polazne hipoteze, navešće se ograničenja istraživanja i sagledaće se otvorena pitanja značajna za buduća istraživanja.

\section{TEORIJA IZGLEDA I SP/A TEORIJA KAO OSNOV RAZVOJA BIHEJVIORALNE PORTFOLIO TEORIJE}

Bihejvioralna portfolio teorija je $\mathrm{u}$ bihejvioralnim finansijama razvijena kao alternativa MPT iz standardnih finansija. Rodonačelnicima BPT smatraju se bihejvioralni ekonomisti H. Shefrin i M. Statman (2000).

H. Shefrin i M. Statman (2000) ističu da su dve teorije izbora u uslovima neizvesnosti poslužile kao osnov za razvoj BPT i to teorija izgleda, čiji su autori D. Kahneman i A. Tversky (1979), i SP/A teorija koju je razvila L. L. Lopes (1987).

Teorija izgleda je deskriptivna teorija odlučivanja u uslovima neizvesnosti. Odlikuje je asimetričan stav prema riziku. Prema teoriji izgleda investitorov stav prema riziku u zoni gubitka se razlikuje od investitorovog stava prema riziku u zoni dobitka. Investitor različito reaguje na podjednako rizične situacije u zavisnosti od toga da li se nalazi u zoni gubitka ili zoni dobitka. U zoni gubitka, investitor pokazuje sklonost prema riziku, dok u zoni dobitka isti investitor pokazuje odbojnost prema riziku. Dakle, investitora ne odlikuje isključivo sklonost prema riziku ili isključivo odbojnost prema riziku, već njegov stav prema riziku varira u zavisnosti od konkretne situacije, odnosno, zone u kojoj se nalazi.

Tvrdnju da investitori u zoni gubitka pokazuju sklonost prema riziku, a u zoni dobitka odbojnost prema riziku, tvorci teorije izgleda D. Kahneman i A. Tversky (1979) su potkrepili rezultatima istraživanja sprovedenog na dve grupe ispitanika. Prvoj grupi od 70 ispitanika autori su ponudili izbor između opcija A i B, pri čemu je opcija A podrazumevala jednaku verovatnoću ostvarenja dobitka od 1000 dolara i ostvarenja nultog dobitka, dok je opcija B podrazumevala siguran dobitak od 500 dolara. Čak 84\% ispitanika je izabralo opciju B, pokazujući odbojnost prema riziku u zoni dobitka. Drugoj grupi od 68 ispitanika ponuđen je izbor između opcija C i D, pri čemu je opcija $C$ podrazumevala jednaku verovatnoću ostvarenja gubitka od 1000 dolara i ostvarenja nultog ishoda (izbegavanje gubitka), dok je opcija D podrazumevala siguran gubitak od 500 dolara. Čak 69\% ispitanika je izabralo opciju C, pokazujući sklonost prema riziku u zoni gubitka.

Sklonost prema riziku koju investitor pokazuje $\mathrm{u}$ zoni gubitka je jedini način da se gubitak izbegne i pretvori u dobitak, dok je odbojnost prema riziku u zoni dobitka najbolji način da se ostvareni dobitak zadrži, obezbedi i osigura. U zoni gubitka, investitori su, u nastojanju da potpuno izbegnu gubitak, spremni da se izlože riziku dodatnog gubitka. S druge strane, u zoni dobitka, investitori nisu spremni da preterano rizikuju kako bi uvećali svoj dobitak. Stoga je prema teoriji izgleda funkcija vrednosti konveksna ispod referentne tačke predstavljene koordinatnim početkom, odnosno, konkavna iznad referentne tačke i podseća na slovo „S“ (Slika 1). Na primer, u zoni gubitka investitori ulažu novac u listiće za lutriju, dok u zoni dobitka kupuju polise osiguranja. Važno je primetiti da je funkcija vrednosti strmija u zoni gubitka nego u zoni dobitka, što govori da investitori snažnije osećaju gubitke.

Ukratko, pojedinci su spremni da se kockaju u zoni gubitka, a istovremno nisu spremni da se kockaju u zoni dobitka. Važno je istaći da se pod gubitkom i dobitkom ne podrazumevaju negativan i pozitivan prinos, tj. smanjenje i povećanje bogatstva, već bogatstvo ispod referentne tačke i bogatstvo iznad referentne tačke. Referentna tačka se razlikuje od investitora do investitora, a određuje se na osnovu ranijih iskustava, uvreženih mišljenja (usidrenja), dostupnih informacija, predviđanja. Nije teško zaključiti da promena referentne tačke implicira i promenu investitorovog stava prema riziku, a samim tim i promenu investitorove odluke. Ukoliko se, usled promene referentne tačke, raniji gubitak percipira kao dobitak, investitori će sklonost prema riziku zameniti odbojnošću prema riziku, a rizičnu investicionu 


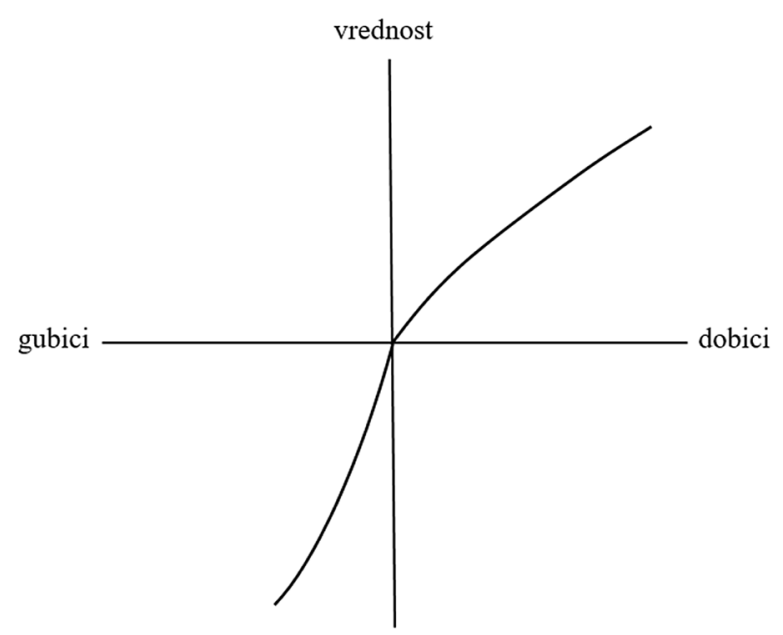

Slika 1 Hipotetička funkcija vrednosti

Izvor: Kahneman \& Tversky, 1979, 279

odluku manje rizičnom. I obrnuto, ukoliko se, usled promene referentne tačke, raniji dobitak percipira kao gubitak, investitori će odbojnost prema riziku zameniti sklonošću prema riziku, a manje rizičnu investicionu odluku rizičnijom.

Treba istaći da teorija izgleda predstavlja alternativu teoriji očekivane korisnosti na kojoj se zasnivala tradicionalna ekonomska teorija, a koja je podrazumevala da svi investitori imaju odbojnost prema riziku, zbog čega je funkcija korisnosti bila konkavna za sve nivoe bogatstva. Za razliku od teorije očekivane korisnosti, kao normativne teorije koja propisuje pravila koja svaki racionalni i potpuno informisani pojedinac treba da sledi kada donosi odluku, teorija izgleda je deskriptivna teorija, jer opisuje kako stvarni pojedinci u stvarnom poslovnom okruženju zaista donose odluke (Cupic, 2015, 221). Teorija izgleda u svojoj osnovi predstavlja kritiku teorije očekivane korisnosti. Prema teoriji izgleda, umesto da se fokusira na maksimiranje ukupnog bogatstva, pojedinac posmatra svaku situaciju odlučivanja kao nezavisan i izolovan događaj i odluku donosi na osnovu dobitaka i gubitaka koji će biti rezultat date odluke, a u odnosu na referentnu tačku (Todorović, 2011, 277). Stoga je funkcija korisnosti ukupnog bogatstva iz teorije očekivane korisnosti, u teoriji izgleda zamenjena funkcijom vrednosti mogućih ishoda u odnosu na referentnu tačku.
Druga teorija izbora u uslovima neizvesnosti, koja je poslužila kao osnov za razvoj BPT, jeste SP/A teorija koju je razvila L. L. Lopes (1987), a dalje je unapređivali L. L. Lopes i G. C. Oden (1999). Nasuprot tvrdnji standardnih finansija da su ljudi savršeno racionalna ekonomska bića, L. L. Lopes (1987) smatra da donošenje svakodnevnih životnih, a među njima i investicionih odluka, uključuje emocionalne aspekte kao što su strah i nada, ali i aspiraciju donosioca odluke. Strah iziskuje sigurnost, a nada potencijal, tj. mogućnost za maksimiranje bogatstva. S tim u vezi, tri osnovna elementa SP/A teorije su: $\mathrm{S}$ - sigurnost, tj. briga o izbegavanju siromaštva, $\mathrm{P}$ - potencijal, tj. želja za maksimiranjem bogatstva i A - aspiracija, tj. težnja za postizanjem postavljenog cilja.

Poput teorije izgleda, i SP/A teorija pripada korpusu deskriptivnih teorija odlučivanja, jer ne propisuje pravila, već opisuje način donošenja odluka. Međutim, za razliku od teorije izgleda koja naglašava kogniciju, tj. kognitivne aspekte odlučivanja poput uokvirivanja u zoni dobitaka ili zoni gubitaka, SP/A teorija naglašava emociju, tj. emocionalne aspekte odlučivanja u uslovima neizvesnosti. Naglašavajući uticaj emocija, SP/A teorija pruža generalni okvir za donošenje odluka. Prema H. Shefrin-u (2016), SP/A teorija teži ravnotežnoj interakciji straha, nade i aspiracije.

Takođe, za razliku od teorije izgleda, SP/A teorija primenjuje dva kriterijuma prilikom odlučivanja: SP - sigurnost-potencijal, i A - aspiracija, odnosno, ambicija donosioca odluke. Navedeni kriterijumi su međusobno nezavisni i neretko u konfliktu, jer često sugerišu različite odluke. U kom pravcu će se konflikt rešiti zavisi od toga da li donosilac odluke pridaje veći značaj prvom ili drugom kriterijumu, odnosno, da li pridaje veći značaj strahu i nadi, ili ambiciji.

Tvorac teorije L. L. Lopes (1987), naglašavajući uticaj emocija, u prvom redu straha i nade, ističe da kod pojedinaca ne dominira uvek jedna emocija nad drugom (strah nad nadom, ili nada nad strahom), već da su ljudi obično „oprezno optimistični“. Pod uticajem straha, investitori precenjuju verovatnoću najgorih ishoda, a pod uticajem nade precenjuju verovatnoću najboljih ishoda. Pod uticajem straha, 
u želji da ostvare sigurnost i izbegnu siromaštvo, investitori kupuju bezrizičnu aktivu, dok pod uticajem nade, $u$ želji da maksimiraju bogatstvo, investiraju u veoma rizičnu aktivu.

Dakle, jedna od važnih implikacija SP/A teorije na koju se snažno oslanja BPT je da su investitori prilikom kreiranja portfolija skloni da kombinuju veoma sigurnu i veoma rizičnu aktivu, čime je stvorena osnova za kasnije razumevanje portfolija kao kolekcije subportfolija, odnosno, piramide sa više slojeva.

Prema H. Shefrin-u (2008), SP/A teorija ima brojne prednosti u odnosu na teoriju izgleda i predstavlja bolju osnovu za razvoj BPT, jer bolje objašnjava kako pojedinci donose odluke i zbog čega bihejvioralni portfolio, istovremeno, sadrži bezrizičnu i veoma rizičnu aktivu. Kasnije, H. Shefrin (2016), ističe da su obe teorije, i teorija izgleda koja naglašava kogniciju i SP/A teorija koja naglašava emociju, podjednako važne, jer su kognicija i emocija međusobno isprepletani koncepti. Drugim rečima, navedene teorije se na određeni način dopunjuju i predstavljaju dva dela iste priče o ulozi psihologije u procesu odlučivanja.

\section{BIHEJVIORALNA PORTFOLIO TEORIJA U FUNKCIJI UNAPREĐENJA UČENJA SAVREMENE PORTFOLIO TEORIJE}

Polazeći od prethodno opisane teorije izgleda i SP/A teorije, BPT tvrdi da investitori istovremeno pokazuju odbojnost i sklonost prema riziku, tj. istovremeno kupuju polise osiguranja i listiće državne lutrije. Nasuprot BPT, alternativna MPT pretpostavlja da investitore karakteriše isključivo odbojnost prema riziku, zbog čega nisu spremni da ulože novac u kupovinu listića državne lutrije (Das, Markowitz, Scheid \& Statman, 2011). Ukoliko racionalni investitor iz MPT bira između kupovine loto listića i ulaganja novca u diversifikovani portfolio, opredeliće se za diversifikovani portfolio, budući da ga odlikuje niža standardna devijacija prinosa kao mera rizika. Pored navedenog, očekivani prinos listića državne lutrije je negativan, dok je očekivani prinos diversifikovanog portfolija pozitivan.

Investitora koji se u opisanoj situaciji opredeli za ulaganje novca u diversifikovani portfolio karakteriše očigledna odbojnost prema riziku. Međutim, u bihejvioralnim finansijama isti investitor se smatra sklonim riziku ukoliko je njegov cilj da u kratkom vremenskom periodu ulaganjem jednog evra zaradi sto miliona evra. U BPT rizik se ne meri standardnom devijacijom prinosa, već se meri verovatnoćom manjka tj. neuspeha $u$ ostvarivanju postavljenog cilja, prosečnom vrednošću manjka, ili njihovim proizvodom. Ukoliko se investitor opredeli za ulaganje novca u diversifikovani portfolio, rizik neuspeha $\mathrm{u}$ ostvarivanju postavljenog cilja biće veći nego u slučaju kupovine listića državne lutrije, zbog čega se ovakav investitor smatra sklonim riziku.

Zaključak navedenog je da portfoliji ocenjeni kao nisko rizični u standardnim finansijama i MPT, mogu biti ocenjeni kao visoko rizični u bihejvioralnim finansijama i BPT usled velike verovatnoće neuspeha u ostvarivanju postavljenog cilja. Slično, portfoliji ocenjeni kao visoko rizični u standardnim finansijama i MPT, mogu biti ocenjeni kao nisko rizični $\mathrm{u}$ bihejvioralnim finansijama i BPT usled male verovatnoće neuspeha u ostvarivanju postavljenog cilja (Statman, 2014).

Ključna odlika BPT je da „normalni“ investitori ne posmatraju svoj portfolio kao celinu, kao što to predlaže MPT, već kao odvojene slojeve mentalnog računa, pri čemu se za svaki sloj mentalnog računa vezuje određeni cilj i određeni nivo tolerancije prema riziku. Dakle, prema BPT ciljevi i stavovi investitora prema riziku variraju po slojevima (Statman, 2008). "Normalni" investitori iz BPT posmatraju svoj portfolio kao kolekciju subportfolija, od kojih je svaki optimalan na datom mentalnom računu (Pfiffelmann et al, 2016).

Portfolio u BPT liči na piramidu sa više slojeva, pri čemu kretanjem od najnižeg ka najvišem sloju piramide ciljevi investitora postaju ambiciozniji, a njihov nivo tolerancije prema riziku viši. U najnižem sloju investitori kupuju polise osiguranja i državne obveznice, u srednjim slojevima kupuju akcije više 
preduzeća i džank obveznice, a u najvišem sloju akcije jednog preduzeća i listiće državne lutrije. Prema H. Shefrin-u (2015), investitori kreiraju slojevite portfolije kako bi istovremeno obezbedili kako zaštitu od rizika, tako i priliku za zaradu. Jedan od načina istovremenog postizanja zaštite od rizika i stvaranja prilike za zaradu u okviru istog portfolija jeste investiranje $\mathrm{u}$ prodajne opcije na nižim slojevima mentalnog računa i istovremeno ulaganje u kupovne opcije na višim slojevima mentalnog računa (Das \& Statman, 2013).

BPT $u$ prvi plan stavlja ciljeve investitora, definisane na pojedinačnim slojevima mentalnog računa. "Normalni“ investitori žele više od pukog pozicioniranja portfolija na efikasnoj granici. Krajnji cilj investitora je da kreirani portfolio zadovolji ciljeve definisane na svakom pojedinačnom sloju portfolio piramide (Das et al, 2011).

U skladu sa prethodno iznetim, M. Statman (2014, 68) ističe da „normalni“ investitori započinju proces kreiranja bihejvioralnog portfolija deljenjem osnovnog portfolija na tri mentalna računa, kao tri sloja u portfolio piramidi. Prvi mentalni račun (najniži sloj u piramidi) služi za zaštitu od siromaštva, drugi mentalni račun (srednji sloj u piramidi) može služiti u svrhu edukacije i treći mentalni račun (najviši sloj u piramidi) je namenjen uvećanju bogatstva. Prvi mentalni račun karakteriše investitorova odbojnost prema riziku, zbog čega su obveznice dominantna aktiva u najnižem sloju. Drugi mentalni račun odlikuje srednji nivo tolerancije prema riziku, zbog čega $\mathrm{u}$ srednjem sloju preovladava kombinacija akcija i obveznica. Konačno, treći mentalni račun odlikuje investitorova sklonost prema riziku, zbog čega su akcije malog broja ili čak jednog preduzeća dominantna aktiva $\mathrm{u}$ najvišem sloju. Prema E. W. Rengifo-u et al, (2014), investitori mogu imati kratku poziciju u određenoj hartiji od vrednosti u jednom sloju piramide $\mathrm{i}$ dugu poziciju $\mathrm{u}$ istoj hartiji od vrednosti u drugom sloju piramide.

Tvrdnja BPT da investitori istovremeno pokazuju odbojnost i sklonost prema riziku, tj. istovremeno kupuju polise osiguranja i listiće državne lutrije objašnjava se upravo prisustvom prethodno opisanog mentalnog računovodstva. Sklonost prema riziku i težnju za povećanjem bogatstva investitori pokazuju na jednom mentalnom računu, a odbojnost prema riziku i težnju za očuvanjem bogatstva pokazuju na drugom mentalnom računu. Prednost mentalnog računovodstva se ogleda $u$ činjenici da je investitoru lakše da odredi svoj nivo tolerancije prema riziku za svaki mentalni račun pojedinačno, nego da to učini za portfolio kao celinu, što zahteva da se svi mentalni računi $u$ mislima investitora sjedine $u$ jedan stvarni račun.

Na ovaj način su bihejvioralni ekonomisti, putem mentalnog računovodstva i prisustva odvojenih računa (račun za sigurnost i račun za rizikovanje radi bogaćenja), uspeli da reše Friedman-Savage-ovu zagonetku (Friedman \& Savage, 1948), tj. da odgovore na jedno od $\mathrm{u}$ finansijskoj literaturi najčešće navođenih zagonetnih pitanja: zašto ljudi istovremeno kupuju polise osiguranja i učestvuju u igrama na sreću?

Pored različitog stava prema riziku i različitog posmatranja portfolija (kao celine i kao kolekcije subportfolija), racionalni investitori iz MPT i „normalni“ investitori iz BPT se rukovode i različitim setom faktora prilikom konstruisanja željenog portfolija. Racionalni investitori konstruišu portfolio, rukovodeći se odnosom očekivanog prinosa i rizika, dok „normalni“ investitori, pored prinosa i rizika, uzimaju u obzir i sopstvene želje, potrebe, sklonosti, navike, preferencije, emocije (Águila, 2009), a neretko se služe i heuristikama, tj. mentalnim prečicama, intuicijom, pa čak i nagađanjem. Drugim rečima, racionalni investitori se prilikom oblikovanja portfolija rukovode isključivo utilitarističkim koristima (visok očekivani prinos i nizak rizik), dok "normalni“ investitori biraju hartije od vrednosti i drugu finansijsku aktivu ne samo na osnovu utilitarističke, već i na osnovu ekspresivne (izražajne) i emocionalne koristi. Cilj racionalnog investitora je da maksimira utilitarističku korist koja se ogleda $\mathrm{u}$ rastu bogatstva, odnosno, maksimiranju prinosa pri datom nivou rizika, dok ",normalni“ investitor nastoji da maksimira sve tri dimenzije koristi.

Prema M. Statman-u (2014, 66), utilitaristička korist daje odgovor na pitanje kakvu praktičnu korist 
od investicije imaju investitor i njegov novčanik. Ekspresivna korist daje odgovor na pitanje šta realizovana investicija govori o investitoru, odnosno, kakav utisak investitor ostavlja na ljude oko sebe. Konačno, emocionalna korist odgovara na pitanje kako se investitor oseća nakon realizovane investicije.

Kupovinom akcija društveno odgovornog preduzeća, koje vodi računa o zaštiti životne sredine, „normalni“ investitor ostvaruje utilitarističku korist u vidu rastućeg bogatstva, ekspresivnu korist jer odaje utisak društveno odgovorne osobe i emocionalnu korist u vidu osećaja zadovoljstva i ponosa. Nasuprot „normalnom" investitoru, racionalni investitor uspeva da odvoji razum od emocija i da se rukovodi isključivo ciljem maksimiranja sopstvenog bogatstva. Racionalni investitor je spreman da investira $u$ visokoprinosne akcije preduzeća koje se bavi proizvodnjom akoholnih pića, čak i ukoliko je kod nekog od članova njegove porodice prisutna bolest zavisnosti od alkoholizma.

Prema M. Statman-u (2014), racionalni investitori uspevaju da odvoje njihovu ulogu od uloge potrošača. Kao investitori ulažu $u$ visokoprinosne akcije preduzeća koje se bavi proizvodnjom oružja, a kao potrošači doniraju određene sume novca kampanjama za kontrolu naoružanja. S druge strane, "normalni“ investitori, čak ni „normalni-obrazovani“ investitori, ne uspevaju da razdvoje navedene funkcije i ne investiraju u akcije opisanih preduzeća.

Budući da su investitori iz MPT i investitori iz BPT rukovođeni različitim ciljevima i različitim setom faktora prilikom kreiranja željenog portfolija, nije teško zaključiti da se efikasna granica u BPT ne podudara sa efikasnom granicom u MPT, kao i da se optimalni portfolio u BPT razlikuje od optimalnog portfolija u MPT (Slika 2).

Takođe, investitori iz MPT se suočavaju sa jednom efikasnom granicom, dok se investitori iz BPT suočavaju sa više efikasnih granica - po jednom za svaki mentalni račun (Das et al, 2011). Stoga, umesto izbora jednog optimalnog portfolija, „normalni“ investitori biraju više optimalnih subportfolija - po jedan za svaki sloj portfolio piramide. Kombinacijom optimalnih subportfolija kreira se optimalni portfolio.
Prema H. Shefrin-u i M. Statman-u (2000, 128), optimalni portfolio u MPT predstavlja kombinaciju tržišnog portfolija i bezrizične aktive, dok optimalni portfolio u BPT, usled kombinacije optimalnih subportfolija, podseća na kombinaciju obveznica i listića državne lutrije.

U MPT, optimalni portfolio varira među investitorima

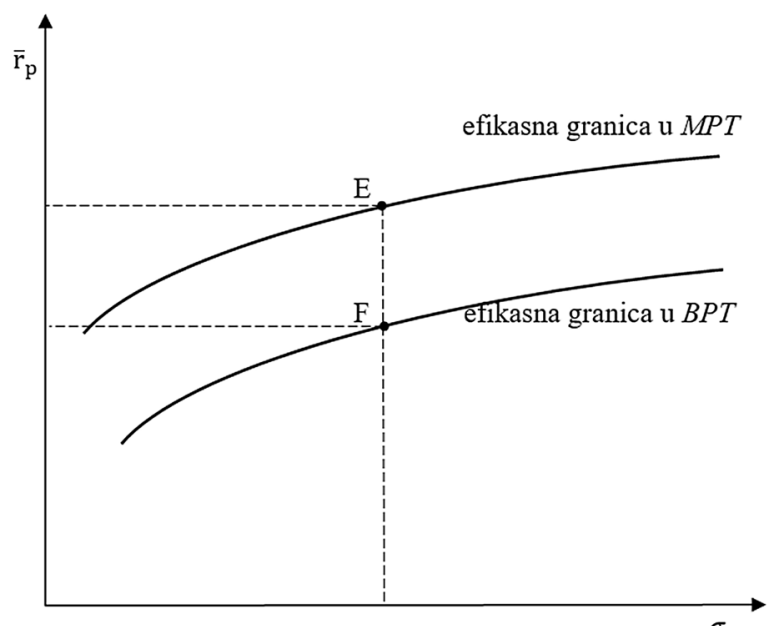

Slika 2 Efikasna granica u BPT nasuprot efikasnoj granici u MPT

Izvor: Statman, 2017b, 44

u zavisnosti od njihovog nivoa tolerancije prema riziku, dok u BPT optimalni portfolio varira među investitorima ne samo usled različitog nivoa tolerancije prema riziku, već i zbog različitih želja, potreba, sklonosti, navika, preferencija i emocija investitora (društvena odgovornost, patriotizam, ponos). C. T. Howard (2014) ističe da je konstruisanje optimalnog portfolija iz MPT emotivno teško, jer podrazumeva zamenu emocija, heuristika i prirodnih reakcija složenom i visoko razumnom analizom.

Iz ugla standardnih finansija i MPT, optimalni portfolio je portfolio koji maksimira utilitarističku korist investitora, tj. pri preferiranom nivou rizika donosi maksimalan očekivani prinos. S druge strane, iz ugla bihejvioralnih finansija i BPT optimalni portfolio je portfolio koji pri preferiranom nivou 
rizika maksimira ukupnu korist investitora izraženu kao zbir utilitarističke, ekspresivne i emocionalne koristi.

Na Slici 2 optimalni portfolio racionalnog investitora koji zanemaruje ekspresivnu i emocionalnu korist je portfolio E, dok je portfolio F optimalni portfolio „normalnog“ investitora koji jednako vrednuje sve tri dimenzije koristi. Portfolio F se nalazi ispod portfolija E, jer želja za ostvarivanjem ekspresivne i emocionalne koristi obično rezultira nižim očekivanim prinosom pri istom nivou rizika. Investitori su spremni da se odreknu dela očekivanog prinosa zarad postizanja ekspresivne i emocionalne koristi, zbog čega se ne samo optimalni portfolio, već i celokupna efikasna granica u BPT nalazi ispod efikasne granice u MPT. Iako portfolio $\mathrm{F}$ ne donosi najvišu utilitarističku korist, on je optimalan jer donosi najvišu ukupnu korist za investitora imajući u vidu sve tri dimenzije koristi.

Prema predstavnicima bihejvioralnih finansija, investitori su spremni da prihvate i negativnu utilitarističku korist u zamenu za trenutnu ili potencijalnu ekspresivnu i emocionalnu korist. Primera radi, spremni su da prihvate negativan očekivani prinos listića državne lutrije, u zamenu za nadu da će dobiti na lutriji. Drugim rečima, spremni $\mathrm{su}$ da prihvate negativnu utilitarističku korist $\mathrm{u}$ zamenu za trenutnu emocionalnu korist $u$ vidu uzbuđenja koje igre na sreću donose, i potencijalnu ekspresivnu i emocionalnu korist u smislu prestiža i uzbuđenja koje eventualni dobitak na lutriji donosi.

Slično, investitor sa visokim nivoom društvene odgovornosti, spreman je da se odrekne visokoprinosnih akcija preduzeća koje se bavi pružanjem kockarskih usluga, proizvodnjom alkohola, duvana, oružja, u zamenu za niskoprinosne akcije preduzeća koje promoviše suprotne vrednosti. Navedena spremnost investitora se ogleda u zameni utilitarističke koristi sa ekspresivnom i emocionalnom koristi. Umanjenu utilitarističku korist investitor uspeva da nadomesti uvećanom ekspresivnom i emocionalnom koristi. U opisanom primeru, akcije društveno odgovornih i društveno neodgovornih preduzeća nisu supstituti zato što obezbeđuju jednak nivo utilitarističke koristi, već zato što obezbeđuju jednak nivo ukupne koristi. M. Statman (2017a) navodi da ruže nisu supstitut za čokoladu zato što imaju nutritivnu vrednost, već zato što pružaju ekpresivnu zahvalnost i emocionalni uticaj.

Uprkos činjenici da se optimalni portfoliji u BPT i MPT razlikuju, rezultati najnovijih istraživanja (Das, Markowitz, Scheid \& Statman, 2010; Pfiffelmann et al, 2016) pokazuju da BPT i MPT rezultiraju znatno sličnijim izborom portfolija nego što je prvobitno bilo pretpostavljeno. U istraživanju koje su sproveli M. Pfiffelmann et al (2016), optimalni portfolio iz BPT se u više od $70 \%$ slučajeva nalazio na efikasnoj granici iz MPT. Istraživanje je sprovedeno bez ograničenja: uzete su u obzir sve, a ne samo birane karakteristike BPT, dozvoljena je prodaja na kratko i nije uvedena pretpostavka o normalnoj distribuciji prinosa. Međutim, rezultati istog istraživanja su pokazali da se optimalni portfolio iz BPT nalazi uvek na gornjem desnom delu efikasne granice koji odlikuje visok nivo rizika. Stoga, prosečan investitor iz standardnih finansija neće izabrati optimalni portfolio iz BPT, uprkos činjenici da se on nalazi na efikasnoj granici. Izbor ovakvog portfolija zahteva nizak nivo odbojnosti prema riziku, što nije odlika prosečnog tradicionalnog investitora. Preciznije, izbor optimalnog portfolija iz BPT zahteva do deset puta niži nivo odbojnosti prema riziku od nivoa odbojnosti prema riziku prosečnog investitora iz standardnih finansija (Pfiffelmann et al, 2016).

Sumiranjem gore iznetog primećuju se brojne razlike između MPT i BPT koje govore u prilog tvrdnji da je BPT razvijena kao alternativa i veliki izazov MPT (Tabela 1).

$\mathrm{Na}$ osnovu ključnih karakteristika MPT i BPT, zaključuje se da je BPT inkorporiranjem psiholoških faktora "otišla korak dalje“, nadogradila i dopunila učenje standardnih finansija i MPT. Preciznije, BPT je nastavila tamo gde je MPT stala i obezbedila svojevrsnu zaokruženost portfolio teorije. Pored maksimiranja utilitarističke koristi, BPT kao jednako važne ciljeve investitora navodi i maksimiranje preostale dve dimenzije koristi: ekspresivne i emocionalne. Na ovaj način, BPT je približila 
portfolio teoriju stvarnosti, jer se investitori $\mathrm{u}$ realnim okvirima ne rukovode isključivo ciljem maksimiranja sopstvenog bogatstva, već vode računa i o društvenoj odgovornosti, konformizmu, socijalnoj prihvaćenosti. Poseban iskorak BPT je napravila primenom koncepta mentalnog računovodstva, kojim je omogućeno investitoru da umesto jednog ima više nivoa tolerancije prema riziku, umesto jednog opšteg cilja više pojedinačnih ciljeva i umesto jednog optimalnog portfolija više optimalnih subportfolija koji obezbeđuju uspešnije zadovoljenje pojedinačnih investitorovih ciljeva. BPT realnije odražava stvarnost $\mathrm{u}$ poređenju sa MPT i zbog činjenice da je uzela $\mathrm{u}$ obzir pravu prirodu ljudi, različite želje, potrebe i sklonosti pojedinaca.

Međutim, još uvek je rano govoriti o superiornosti BPT nad MPT, jer se obe teorije suočavaju sa ozbiljnim ograničenjima koja opisuje G. Curtis (2004). Primenom tehnika MPT, finansijski savetnici predlažu investitorima portfolio koji je optimalan sa aspekta odnosa između prinosa i rizika, ali je verovatnoća da će se investitori pridržavati dobijenog predloga mala.

Tabela 1 Sumarni prikaz ključnih razlika između MPT i BPT

\begin{tabular}{|c|c|}
\hline MPT & BPT \\
\hline $\begin{array}{l}\text { Investitori su savršeno racionalni ljudi, koji uspevaju da } \\
\text { odvoje razum od emocija i rukovode se isključivo ciljem } \\
\text { maksimiranja sopstvenog bogatstva. }\end{array}$ & $\begin{array}{l}\text { Investitori su „,normalni“, obični ljudi, koji pod uticajem } \\
\text { kognitivnih pristrasnosti i obmanjujućih emocija ne donose } \\
\text { uvek racionalne odluke i ne rukovode se isključivo ciljem } \\
\text { maksimiranja ličnih interesa. }\end{array}$ \\
\hline Investitore karakteriše isključivo odbojnost prema riziku. & $\begin{array}{l}\text { Investitori istovremeno pokazuju odbojnost i sklonost } \\
\text { prema riziku. }\end{array}$ \\
\hline $\begin{array}{l}\text { Rizik se meri varijansom, odnosno, standardnom } \\
\text { devijacijom prinosa. }\end{array}$ & $\begin{array}{l}\text { Rizik se meri verovatnoćom manjka tj. neuspeha u } \\
\text { ostvarivanju postavljenog cilja, prosečnom vrednošću } \\
\text { manjka, ili njihovim proizvodom. }\end{array}$ \\
\hline $\begin{array}{l}\text { Investitori posmatraju portfolio kao celinu i ne primenjuju } \\
\text { koncept mentalnog računovodstva. }\end{array}$ & $\begin{array}{l}\text { Investitori posmatraju portfolio kao kolekciju subportfolija } \\
\text { od kojih je svaki optimalan na datom mentalnom računu. }\end{array}$ \\
\hline $\begin{array}{l}\text { Investitori imaju jedan nivo tolerancije prema riziku koji } \\
\text { važi za portfolio kao celinu. }\end{array}$ & $\begin{array}{l}\text { Investitori imaju više nivoa tolerancije prema riziku, po } \\
\text { jedan za svaki mentalni račun. }\end{array}$ \\
\hline $\begin{array}{l}\text { Investitori imaju jedan sveobuhvatan cilj (maksimiranje } \\
\text { prinosa pri preferiranom nivou rizika), koji važi za portfolio } \\
\text { kao celinu. }\end{array}$ & $\begin{array}{l}\text { Investitori imaju više pojedinačnih ciljeva (zaštita od } \\
\text { siromaštva, edukacija, uvećanje bogatstva), po jedan za } \\
\text { svaki mentalni račun. }\end{array}$ \\
\hline $\begin{array}{l}\text { Investitori konstruišu portfolio rukovodeći se isključivo } \\
\text { odnosom očekivanog prinosa i rizika. }\end{array}$ & $\begin{array}{l}\text { Investitori konstruišu portfolio rukovodeći se kako } \\
\text { odnosom očekivanog prinosa i rizika, tako i sopstvenim } \\
\text { željama, potrebama, navikama, emocijama. }\end{array}$ \\
\hline Investitori se suočavaju sa jednom efikasnom granicom. & $\begin{array}{l}\text { Investitori se suočavaju sa više efikasnih granica - po } \\
\text { jednom za svaki mentalni račun. }\end{array}$ \\
\hline Investitori biraju jedan optimalni portfolio. & $\begin{array}{l}\text { Investitori biraju više optimalnih subportfolija - po jedan za } \\
\text { svaki sloj portfolio piramide. }\end{array}$ \\
\hline $\begin{array}{l}\text { Optimalni portfolio predstavlja kombinaciju tržišnog } \\
\text { portfolija i bezrizične aktive. }\end{array}$ & $\begin{array}{l}\text { Optimalni portfolio nastaje integracijom optimalnih } \\
\text { subportfolija i podseća na kombinaciju obveznica i listića } \\
\text { državne lutrije. }\end{array}$ \\
\hline $\begin{array}{l}\text { Optimalni portfolio je portfolio koji maksimira } \\
\text { utilitarističku korist investitora. }\end{array}$ & $\begin{array}{l}\text { Optimalni portfolio je portfolio koji maksimira ukupnu } \\
\text { korist investitora, izraženu kao zbir utilitarističke, } \\
\text { ekspresivne i emocionalne koristi. }\end{array}$ \\
\hline $\begin{array}{l}\text { Optimalni portfolio varira među investitorima u zavisnosti } \\
\text { od njihovog nivoa tolerancije prema riziku. }\end{array}$ & $\begin{array}{l}\text { Optimalni portfolio varira među investitorima kako } \\
\text { usled različitog nivoa tolerancije prema riziku, tako i } \\
\text { zbog različitih želja, potreba, sklonosti, navika i emocija } \\
\text { investitora. }\end{array}$ \\
\hline
\end{tabular}


S druge strane, primenom tehnika BPT, finansijski savetnici predlažu investitorima portfolio koji će biti rado prihvaćen, ali koji, verovatno, nije optimalan sa aspekta odnosa između prinosa i rizika. U oba slučaja, investitor kao klijent finansijskog savetnika biće razočaran - u prvom slučaju jer nije poštovao savet finansijjkog stručnjaka, a u drugom slučaju jer je poštovao savet finansijskog stručnjaka (Curtis, 2004, 19).

\section{BIHEJVIORALNI MODEL VREDNOVANJA AKTIVE KAO ALTERNATIVA MODELIMA STANDARDNIH FINANSIJA}

Prema bihejvioralnoj finansijskoj teoriji, da bi se u potpunosti razumeo proces vrednovanja i kretanja cene finansijske aktive, neophodno je razumeti psihologiju tržišnih učesnika (Fakhry, 2016, 458). Očekivani prinos hartija od vrednosti ne varira samo usled razlika $u$ nivou rizika koji se vezuje za određenu hartiju od vrednosti. Pored rizika, postoje brojni psihološki faktori, koji utiču na investitorov izbor, cenu hartija od vrednosti, i u krajnjoj liniji, na očekivani prinos (Hirshleifer, 2001). Psihološki faktori koji idu u prilog izbora određene hartije od vrednosti, posredstvom povećane tražnje podižu cenu, a snižavaju prinos te hartije. I obrnuto, psihološki faktori koji ne idu u prilog izbora određene hartije od vrednosti, posredstvom umanjene tražnje snižavaju cenu, a povećavaju prinos hartije.

Polazeći od prethodno iznetog, H. Shefrin i M. Statman (1994) su, kao alternativu standardnim modelima vrednovanja finansijske aktive: modelu vrednovanja kapitalne aktive (Capital Asset Pricing Model - CAPM), Fama-French trofaktorskom modelu, Carhart-ovom četvorofaktorskom modelu i teoriji arbitražnog vrednovanja (Arbitrage Pricing Theory APT), razvili BAPM model.

Prema CAPM modelu, beta koeficijent, kao mera sistemskog rizika je jedini faktor od kojeg zavisi visina očekivanog prinosa. Fama-French trofaktorski model, pored beta koeficijenta, ističe veličinu preduzeća merenu tržišnom kapitalizacijom i odnos knjigovodstvene prema tržišnoj vrednosti preduzeća
(B/M racio) kao ključne faktore rizika i indikatore budućih prinosa. Carhart-ov četvorofaktorski model proširuje Fama-French trofaktorski model dodavanjem momentuma (inercije) kao četvrtog faktora, dok prema APT modelu visina očekivanog prinosa zavisi od većeg broja faktora, ali ovaj model ne precizira o kojim faktorima je reč.

Sa povećanjem broja faktora, složenost modela raste, čime oni gube na jednostavnosti. Međutim, kao što M. Statman (2008) ističe, investitorima, portfolio menadžerima i finansijskim stručnjacima nisu potrebni jednostavni modeli, već modeli koji opisuju stvarne ljude na stvarnim tržištima - a to su upravo modeli bihejvioralnih finansija. Bihejvioralne finansije nude BAPM model koji nije ništa manje jednostavan od standardnih modela, a bliži je stvarnosti.

Tvorci BAPM modela, H. Shefrin i M. Statman (1994), ističu da osnovne standardne teorije, CAPM model i hipoteza efikasnog tržišta (Efficient Market Hypothesis EMH), koje nazivaju teorijama blizancima, važe samo na tržištima na kojima su svi učesnici racionalni i savršeno informisani. Međutim, problem je što ovakva tržišta ne predstavljaju realnu, već idealizovanu sliku stvarnosti. U realnosti, na stvarnim tržištima, pored racionalnih i savršeno informisanih investitora, postoje i nepotpuno informisani investitori podložni kognitivnim greškama i skloni iracionalnim odlukama. Iracionalni optimisti ili pesimisti svojim delovanjem čine tržište neefikasnim, a CAPM model nevažećim. Prema M. M. Pompian-u (2006, 272), u većini slučajeva investitori nisu svesni sopstvene predispozicije za pogrešno postupanje i iracionalno delovanje.

Nasuprot tvrdnji tradicionalnih ekonomista da racionalni investitori uspevaju da ponište uticaj iracionalnih investitora, jer preduzimaju kupovne transakcije nasuprot prodajnih transakcija iracionalnih investitora, odnosno, prodajne transakcije nasuprot kupovnih transakcija iracionalnih investitora, bihejvioralni ekonomisti jasno ukazuju na ograničenost arbitraže. Drugim rečima, dok standardna finansijska teorija tvrdi da je uticaj iracionalnog ponašanja tržišnih učesnika irelevantan, jer tržišne snage uspevaju da vrate cene 
na tržišni nivo (Lo, 2005, 21), bihejvioralna finansijska teorija naglašava uticaj iracionalnog delovanja prouzrokovanog dejstvom različitih psiholoških faktora.

Uspešnim inkorporiranjem psiholoških faktora u proces vrednovanja finansijske aktive, BAPM model je napravio iskorak u odnosu na modele standardnih finansija (Chandra \& Thenmozhi, 2017). Prema D. Hirshleifer-u (2001), na psihologiji zasnovani modeli vrednovanja aktive su prilika da se „uhvati korak sa realnošću“. M. Statman (2014) upozorava da su istraživači isuviše zauzeti pronalaženjem novih faktora i utvrđivanjem statistički značajne vezeizmeđu tih faktora i ostvarenih prinosa, da bi se zapitali da li uopšte postoji teorijska racionalnost $\mathrm{u}$ tom odnosu. U savremeno doba, broj utvrđenih faktora koji su u statistički značajnoj vezi sa ostvarenim prinosom konstantno raste. Međutim, M. Statman (2014) ističe da je teorijska racionalnost podjednako važna kao i statistička značajnost. Statistička značajnost odnosa između faktora i ostvarenih prinosa može biti visoka, a teorijska racionalnost izuzetno niska, i obrnuto. Teorijska racionalnost je od krucijalne važnosti, jer njeno odsustvo praktično poništava utvrđenu statističku značajnost.

Pored pridavanja različitog značaja nepotpuno informisanim investitorima i njihovim iracionalnim odlukama, važna razlika između standardnih modela vrednovanja finansijske aktive i BAPM modela ogleda se u činjenici da standardni modeli vrednuju aktivu na osnovu njene utilitarističke koristi, dok BAPM model vrednuje aktivu ne samo na osnovu njene utilitarističke koristi, već i na osnovu ekspresivne i emocionalne koristi. Dakle, prema BAPM modelu, aktiva vredi zato što donosi kako utilitarističku korist (nizak rizik, visok prinos), tako i ekspresivnu korist (društvena odgovornost, patriotizam), kao i emocionalnu korist (zadovoljstvo, ponos, uzbuđenje koje izaziva trgovanje).

Ne treba izgubiti iz vida ni činjenicu da na vrednost aktive, pored utilitarističke, ekspresivne i emocionalne koristi, utiču i kognitivne greške i obmanjujuće emocije, poput situacije kada investitori različito doživljavaju akcije jednog te istog preduzeća u zavisnosti od informacije o njegovoj veličini.
Ukoliko finansijski analitičar saopšti investitorima da se radi o velikom preduzeću, pojaviće se pozitivna emocija, dok će se negativna emocija pojaviti u slučaju informacije o maloj veličini preduzeća, iako istraživanja pokazuju da akcije preduzeća male tržišne kapitalizacije obično donose viši prinos.

Zaključuje se da je prema BAPM modelu očekivani prinos aktive funkcija utilitarističke koristi, ekspresivne koristi, emocionalne koristi, ali i kognitivnih grešaka i obmanjujućih emocija. Primera radi, očekivani prinos akcija nekog preduzeća je funkcija rizika, likvidnosti, društvene odgovornosti, prestiža, uzbuđenja, kao i kognitivnih grešaka i obmanjujućih emocija.

Preferiranje akcija nekog preduzeća, zahvaljujući njihovim ekspresivnim i emocionalnim koristima, znači veću tražnju i višu cenu, a niži očekivani prinos, tj. nižu utilitarističku korist. $S$ tim u vezi, ne treba da čudi što, na primer, akcije društveno odgovornih preduzeća imaju niži očekivani prinos od akcija preduzeća koja se bave proizvodnjom oružja, alkohola i cigareta (Hong \& Kacperczyk, 2009; Statman, 2014). Ukratko, veća ekspresivna i emocionalna korist rezultiraju nižom utilitarističkom koristi. Stoga, kao što je već objašnjeno, optimalni portfolio u bihejvioralnim finansijama, po pravilu, donosi niži očekivani prinos pri istom nivou rizika od optimalnog portfolija u standardnim finansijama.

Pomoću razlika u utilitarističkoj, ekspresivnoj i emocionalnoj koristi, objašnjavaju se i razlike u cenama realne aktive. Automobil marke Mercedes i automobil marke Dačija pružaju isti nivo utilitarističke koristi u smislu prevoza putnika sa jednog mesta na drugo, ali automobil marke Mercedes obezbeđuje veću ekspresivnu korist u vidu prestiža, stila i prefinjenog ukusa, kao i veću emocionalnu korist u vidu većeg zadovoljstva i ponosa. Veća ekspresivna i emocionalna korist rezultiraju višom cenom koju su potrošači spremni da plate prilikom kupovine automobila marke Mercedes. U navedenom primeru, očekivana cena automobila je funkcija njegove korisnosti kao prevoznog sredstva, prestiža, stila, prefinjenog ukusa, zadovoljstva, ponosa, kognitivnih grešaka i obmanjujućih emocija. 
Prema M. Statman-u (2017a), modeli vrednovanja finansijske aktive se mogu uporediti sa modelima vrednovanja jela, automobila, filmova i svih drugih dobara i usluga. Večera u restoranu vredi zato što donosi ne samo utilitarističku korist (nutritivna vrednost), već i ekspresivnu korist (prestiž) i emocionalnu korist (zadovoljstvo, dobar ukus, estetika). S tim u vezi, nikoga ne čudi činjenica da je obrok $\mathrm{u}$ restoranu skuplji od obroka iste nutritivne vrednosti kupljenog u marketu. I u slučaju vrednovanja dobara i usluga ne treba izgubiti iz vida kognitivne i emocionalne greške, poput situacije kada potrošači doživljavaju jedno te isto vino na različite načine u zavisnosti od informacije o njegovoj ceni. Naznačena viša cena vina stvara privid boljeg kvaliteta, izaziva osećaj većeg uživanja i prijatnijeg ukusa, dok niža cena istog vina izaziva suprotne predrasude. Slično, potpuno iste naočare za sunce potencijalni kupac će doživeti kao kvalitetne i prijatne za vid u slučaju navođenja visoke cene tih naočara, odnosno, kao nekvalitetne i neprijatne za vid u slučaju navođenja niske cene naočara.

Ovde je važno naglasiti da standardne finansije potpuno zanemaruju afekat prilikom vrednovanja finansijske aktive, dok u BAPM modelu afekat ima naročito važnu ulogu. Prema P. Slovic-u, M. L. Finucane-u, E. Peters-u i D. G. MacGregor-u (2007), afekat je nezaobilazna komponenta ljudskog rasuđivanja i odlučivanja. Afekat je kratkotrajno pozitivno ili negativno osećanje koje ubrzava proces donošenja odluka. Sam pomen marke automobila, mobilnog telefona, sata, kod potencijalnog kupca izaziva osećaj poželjnosti ili nepoželjnosti. Slično je i sa akcijama preduzeća. Akcije društveno odgovornih preduzeća, koja vode računa o zaštiti životne sredine, izazivaju pozitivan afekat i poželjniji su izbor $u$ odnosu na akcije preduzeća koja proizvode alkohol, oružje ili cigarete.

Pozitivan afekat smanjuje nivo rizika $\mathrm{u}$ očima pojedinca (investitora), dok negativan afekat pojačava doživljaj ukupnog rizika. Negativan afekat je izvor visokog subjektivnog rizika, dok je nizak subjektivni rizik posledica pozitivnog afekta. Za razliku od standardnih finansija, koje ne poznaju kategoriju subjektivnog rizika, bihejvioralne finansije pod ukupnim rizikom podrazumevaju objektivni rizik uvećan za nivo subjektivnog rizika. Dakle, standardne finansije tretiraju rizik kao objektivnu kategoriju, dok bihejvioralne finansije, prema N. Linciano-u (2010), tvrde da rizik i nesigurnost nisu samo matematički i statistički, već i psihološki koncepti. Takođe, standardne finansije naglašavaju kvantitativne aspekte rizika i pretpostavljaju pozitivnu korelaciju između prinosa i rizika, dok bihejvioralne finansije $\mathrm{u}$ prvi plan stavljaju kvalitativne aspekte rizika i nastoje da objasne pojavu negativne korelacije između prinosa i rizika (Ricciardi, 2008).

Potencijalnu negativnu korelaciju između prinosa i rizika, bihejvioralni ekonomisti objašnjavaju prisustvom subjektivnog rizika. U situaciji relativno niskog objektivnog rizika, očekivani prinos može biti visok kao posledica negativnog afekta, odnosno, visokog subjektivnog rizika. Negativan afekat povećava nivo rizika u očima pojedinca i smanjuje tražnju za aktivom čija se cena smanjuje, a očekivani prinos raste. I obrnuto, u situaciji relativno visokog objektivnog rizika, očekivani prinos može biti nizak kao posledica pozitivnog afekta, odnosno, niskog subjektivnog rizika. Pozitivan afekat smanjuje nivo rizika u očima pojedinca i povećava tražnju za aktivom čija cena raste, a očekivani prinos se smanjuje.

Dakle, prema BAPM modelu afekti snažno utiču na vrednovanje finansijske aktive, jer investitori preferiraju aktivu sa pozitivnim afektom, a izbegavaju aktivu sa negativnim afektom. Investitori u slučaju pozitivnog afekta doživljavaju finansijsku aktivu kao visoko korisnu i bezrizičnu, dok u slučaju negativnog afekta istu aktivu doživljavaju kao nisko korisnu i rizičnu (Linciano, 2010). Pozitivne preferencije investitora podižu cenu aktive, dok negativne preferencije negativno utiču na cenu aktive.

Dodatni faktor koji može uticati na proces finansijskog odlučivanja i na vrednovanje realne i finansijske aktive jesu mentalne šeme. Mentalne šeme su subjektivni doživljaji koji deluju spontano na nesvesnom nivou i mogu uticati na proces percepcije i zaključivanja. Povezivanjem mirisa krofni sa ugodnim periodom detinjstva i toplinom porodičnog doma, aktivira se mentalna šema koja nesvesno podstiče kupovinu proizvoda, čak i ako je sitost dominantan 
osećaj. Slično, investitori se pod uticajem aktiviranih mentalnih šema neretko opredeljuju za kupovinu akcija lokalnih preduzeća u kojima su njihovi roditelji bili zaposleni, ili za kupovinu zemljišta koje je nekada bilo u vlasništvu njihove porodice. Na ovaj način, delovanjem mentalnih šema povećava se tražnja za navedenom aktivom, što rezultira rastom njene cene.

Kao posledica aktiviranja mentalnih šema, neretko se javljaju i iracionalne odluke. Prilikom rešavanja stambenog pitanja, pojedinac će u situaciji izbora kupovine između dve kuće istih karakteritika (kvadratura, lokacija, dvorišni prostor) izabrati onu koja ga podseća na porodičnu i za istu biti spreman da izdvoji znatno veću sumu novca. Navedena i slične iracionalne odluke investitora čine da cena realne i finansijske aktive ne odražava njenu stvarnu vrednost.

Sumiranjem napred iznetog, primećuju se brojne razlike između BAPM modela i standardnih modela vrednovanja aktive koje govore $u$ prilog tvrdnji da je BAPM model razvijen kao alternativa i veliki izazov modelima vrednovanja aktive iz standardnih finansija (Tabela 2).
Imajući u vidu izložene ključne odlike standardnih modela vrednovanja aktive i BAPM modela, zaključuje se da je BAPM model inkorporiranjem psiholoških faktora približio teorijsko vrednovanje aktive stvarnosti. Napredak je postignut i zahvaljujući činjenici da je ovaj, na psihologiji zasnovan model, vrednovanja aktive uvažio koncept ograničenosti arbitraže i samim tim istakao uticaj iracionalnog ponašanja tržišnih učesnika. BAPM model je uključio utilitarističku korist iz standardnih finansija i dodao ekspresivnu i emocionalnu korist kao jednako važne determinante vrednosti finansijske aktive, zbog čega se opravdano smatra nadogradnjom standardnih modela vrednovanja finansijske aktive. Preciznije, BAPM model je uključio, ne samo rizik kao elemenat standardnih finansija, već i brojne psihološke elemente, poput pozitivnog i negativnog afekta i mentalnih šema, dopunjujući na ovaj način modele vrednovanja finansijske aktive zastupljene $\mathrm{u}$ standardnim finansijama.

Prethodno navedeno govori $\mathrm{u}$ prilog superiornosti BAPM modela nad standardnim modelima vrednovanja finansijske aktive. Međutim, kao što ističe N. Barberis (2018), još uvek je rano za donošenje

Tabela 2 Sumarni prikaz ključnih razlika između standardnih modela vrednovanja aktive i BAPM modela

\begin{tabular}{l|l}
\hline Standardni modeli vrednovanja aktive & BAPM model \\
\hline Očekivani prinos aktive varira usled razlika u nivou rizika. & $\begin{array}{l}\text { Očekivani prinos aktive varira kako usled razlika u nivou } \\
\text { rizika, tako i pod uticajem brojnih psiholoških faktora. } \\
\text { Uticaj iracionalnog ponašanja tržišnih učesnika je važan, } \\
\text { jer racionalni investitori ne uspevaju da ponište uticaj } \\
\text { iracionalnih investitora, što govori o ograničenosti } \\
\text { arbitraže. }\end{array}$ \\
$\begin{array}{l}\text { Uticaj iracionalnog ponašanja tržišnih učesnika je } \\
\text { uticaj iracionalnih investitora. }\end{array}$ & $\begin{array}{l}\text { Aktiva se vrednuje ne samo na osnovu njene utilitarističke } \\
\text { koristi, već i na osnovu ekspresivne i emocionalne koristi. }\end{array}$ \\
$\begin{array}{l}\text { Aktiva se vrednuje na osnovu utilitarističke koristi koju } \\
\text { donosi. }\end{array}$ & $\begin{array}{l}\text { Na vrednost aktive utiču kognitivne greške i obmanjujuće } \\
\text { emocije. }\end{array}$ \\
$\begin{array}{l}\text { Na vrednost aktive ne utiču kognitivne greške i } \\
\text { obmanjujuće emocije. }\end{array}$ & $\begin{array}{l}\text { Afekti snažno utiču na vrednovanje finansijske aktive. } \\
\text { Afekti nemaju uticaj na vrednovanje finansijske aktive. }\end{array}$ \\
$\begin{array}{l}\text { Mentalne šeme nemaju uticaj na vrednovanje finansijske } \\
\text { aktive. }\end{array}$ & $\begin{array}{l}\text { Mentalne šeme snažno utiču na vrednovanje finansijske } \\
\text { aktive. }\end{array}$ \\
$\begin{array}{l}\text { Rizik je objektivna kategorija na koju ne utiču afekti, te } \\
\text { stoga ne predstavlja psihološki, već isključivo matematički i i } \\
\text { statistički koncept. }\end{array}$ & $\begin{array}{l}\text { Ukupan rizik se sastoji od objektivnog i subjektivnog rizika, } \\
\text { te stogredstavlja ne samo matematički i statistički, već i }\end{array}$ \\
\hline
\end{tabular}


konačnih zaključaka, jer je na psihološkim faktorima zasnovan bihejvioralni pristup vrednovanju aktive još uvek relativno mlad za razliku od tradicionalnog pristupa koji se pojavio čak tri decenije ranije.

\section{ZAKLJUČAK}

Sumarni prikazi ključnih razlika između MPT i BPT, odnosno, između standardnih modela vrednovanja aktive i BAPM modela, nedvosmisleno potvrđuju činjenicu da su BPT i BAPM model razvijeni kao alternativa i veliki izazov standardnoj finansijskoj teoriji. BPT i BAPM model, uključivanjem i boljim razumevanjem uticaja psiholoških faktora obezbeđuju zaokruženost portfolio teorije i modela vrednovanja finansijske aktive. Bolje razumevanje uticaja psiholoških faktora omogućava investitorima da prevaziđu kognitivne greške i da se odupru uticaju obmanjujućih emocija. Poznavanje psiholoških elemenata, njihove uloge i značaja doprinosi unapređenju efikasnosti portfolio menadžmenta. Takođe, bolje razumevanje uticaja psiholoških faktora i procesa investicionog odlučivanja uopšte, implicira i bolje razumevanje načina vrednovanja finansijske aktive, a samim tim i efikasniju alokaciju aktive.

Za razliku od teorija i modela standardnih finansija, koji investitorima sugerišu kako treba da donose investicione odluke (normativni pristup), BPT i BAPM model nastoje da objasne kako pojedinačni investitori zaista donose odluke u praksi (pozitivni pristup). Takođe, za razliku od teorija i modela standardnih finansija, koji usled primene suviše restriktivnih pretpostavki i egzaktnih pravila nauke ne uspevaju da objasne kompleksnu finansijsku stvarnost, BPT i BAPM model inkorporiranjem koncepta mentalnog računovodstva, ograničene racionalnosti, ekspresivne i emocionalne koristi i koncepta ograničenosti arbitraže, uspevaju da približe finansijsku teoriju stvarnosti i da dopune učenje standardnih finansija, čime je potvrđena polazna hipoteza rada. Uprkos navedenom, prerano je i preambiciozno govoriti o superiornosti BPT i BAPM modela u odnosu na MPT i standardne modele vrednovanja finansijske aktive, jer se i bihejvioralni i standardni pristup suočavaju sa ozbiljnim ograničenjima. Prethodno iznete tvrdnje predstavljaju ključni zaključak i rezultat istraživanja koji je kompatibilan sa zaključcima do kojih su došli G. Curtis (2004) i N. Barberis (2018).

U teorijskom smislu, doprinos rada se ogleda $u$ činjenici da predstavlja prvo kvalitativno istraživanje BPT i BAPM modela u domaćoj literaturi, zbog čega podrazumevano doprinosi boljem razumevanju ovih relativno mladih teorijskih okvira. Takođe, teorijski doprinos rada se ogleda $u$ identifikovanju i sumarnom prikazu ključnih razlika između BPT i MPT, odnosno, između BAPM modela i standardnih modela vrednovanja aktive.

U praktičnom smislu, bolje razumevanje i primena BPT i BAPM modela može biti od velike koristi investitorima, portfolio menadžerima, finansijskim stručnjacima i ostalim učesnicima na tržištu, u smislu unapređenja investicione aktivnosti, efikasnijeg portfolio menadžmenta, pravilnijeg vredovanja i efikasnije alokacije aktive.

Osnovno ograničenje rada ogleda se u odsustvu originalnog empirijskog istraživanja i empirijske verifikacije polazne hipoteze rada. U sprovedenom istraživanju nije izvršena empirijska analiza kojom bi se postulati i koristi primene BPT i BAPM modela uporedili sa postulatima i koristima primene teorija i modela standardnih finansija. Sprovođenje odgovarajućeg empirijskog istraživanja zahteva opsežnu kvantitativnu analizu koja prevazilazi okvire ovog rada i predstavlja predlog za buduća istraživanja u ovoj oblasti.

Buduća istraživanja mogu biti usmerena i na traženje optimalnog rešenja koje pomiruje suprostavljene stavove tradicionalnih i bihejvioralnih ekonomista. Navedeno može biti postignuto primenom eklektičkog pristupa, u smislu sinergije znanja i kombinovanja najboljih elemenata bihejvioralnih i standardnih finansija.

\section{REFERENCE}

Águila, N. D. (2009). Behavioral Finance: Learning from market anomalies and psychological factors. Revista de Instituciones, Ideas y Mercados, 50, 47-104. 
Bakar, S., \& Yi, A. N. C. (2016). The Impact of psychological factors on investors' decision making in Malaysian stock market: A case of klang valley and pahang. Procedia Economics and Finance, 35, 319-328. doi.org/10.1016/S22125671(16)00040-X

Barberis, N. (2018). Psychology-based models of asset prices and trading volume. NBER Working Paper No. 24723. National Bureau of Economic Research. doi.org/10.2139/ ssrn.3177616

Blanco, F. (2017). Cognitive bias. In J. Vonk \& T. Shackelford (Eds.). Encyclopedia of Animal Cognition and Behavior (pp. 1-6). Cham: Springer. doi.org/10.1007/978-3-319-47829-6_1244-1

Brajković, A., \& Peša, A. R. (2015). Bihevioralne financije i teorija „Crnog labuda“. Oeconomica Jadertina, 1, 65-93.

Chandra, A., \& Thenmozhi, M. (2017). Behavioural asset pricing: Review and synthesis. Journal of Interdisciplinary Economics, 29(1), 1-31. doi.org/10.1177/0260107916670559

Cupic, M. (2015). Risk management and corporate value. Economic Horizons, 17(3), 215-228.

Curtis, G. (2004). Modern portfolio theory and behavioral finance. The Journal of Wealth Management, 7(2), 16-22. doi. org/10.3905/jwm.2004.434562

Das, S., Markowitz, H., Scheid, J., \& Statman, M. (2010). Portfolio optimization with mental accounts. Journal of Financial and Quantitative Analysis, 45(2), 311-334. doi. org/10.1017/S0022109010000141

Das, S., Markowitz, H., Scheid, J., \& Statman, M. (2011). Portfolios for investors who want to reach their goals while staying on the mean-variance efficient frontier. The Journal of Wealth Management, 14(2), 25-31. doi.org/10.3905/ jwm.2011.14.2.025

Das, S., \& Statman, M. (2013). Options and structured products in behavioral portfolios. Journal of Economic Dynamics and Control, 37(1), 137-153. doi.org/10.1016/j.jedc.2012.07.004

De Bondt, W. F. M., Muradoglu, Y. G., Shefrin, H., \& Staikouras, S. K. (2008). Behavioral finance: Quo vadis? Journal of Applied Finance, 18(2), 7-21.

De Bondt, W. F. M., Mayoral, R. M., \& Vallelado, E. (2013). Behavioral decision-making in finance: An overview and assessment of selected research. Spanish Journal of Finance and Accounting, 42(157), 99-118. doi.org/10.1080/02102412.20 13.10779742
Fakhry, B. (2016). A literature review of behavioural finance. Journal of Economics Library, 3(3), 458-465. doi.org/10.1453/jel. v3i3.929

Friedman, M., \& Savage, L. J. (1948). The utility analysis of choices involving risk. The Journal of Political Economy, 56(4), 279-304. doi.org/10.1086/256692

Hirshleifer, D. (2001). Investor psychology and asset pricing. The Journal of Finance, 56(4), 1533-1597. doi.org/10.1111/00221082.00379

Hong, H., \& Kacperczyk, M. (2009). The price of sin: The effects of social norms on markets. Journal of Financial Economics, 93(1), 15-36. doi.org/10.1016/j.jfineco.2008.09.001

Howard, C. T. (2014). Behavioral portfolio management. Journal of Behavioral Finance \& Economics, Forthcoming. Retrieved June 30, 2019 from https://papers.ssrn.com/sol3/ papers.cfm?abstract_id $=2210032$

Kahneman, D., \& Tversky, A. (1979). Prospect theory: An analysis of decision under risk. Econometrica, 47(2), 263-292.

Linciano, N. (2010). Cognitive biases and instability of preferences in the portfolio choices of retail investors. Working Paper No. 66, Commissione Nazionale per le Societa e la Borsa. doi.org/10.2139/ssrn.1898560

Lo, A. W. (2005). Reconciling efficient markets with behavioral finance: The adaptive markets hypothesis. The Journal of Investment Consulting, 7(2), 21-44.

Lopes, L. L. (1987). Between hope and fear: The psychology of risk. Advances in Experimental Social Psychology, 20, 255-295. doi.org/10.1016/S0065-2601(08)60416-5

Lopes, L. L., \& Oden, G. C. (1999). The role of aspiration level in risk choice: A comparison of cumulative prospect theory and SP/A theory. Journal of Mathematical Psychology, 43, 286313. doi.org/10.1006/jmps.1999.1259

Muradoglu, G., \& Harvey, N. (2012). Behavioral finance: The role of psychological factors in financial decisions. Review of Behavioral Finance, 4(2), 68-80. doi. org/10.1108/19405971211284862

Pfiffelmann, M., Roger, T., \& Bourachnikova, O. (2016). When behavioral portfolio theory meets Markowitz theory. Economic Modelling, 53, 419-435. doi.org/10.1016/j. econmod.2015.10.041

Pompian, M. M. (2006). Behavioral Finance and Wealth Management. Hoboken, New Jersey: Wiley \& Sons, Inc. 
Rengifo, E. W., Trendafilov, R., \& Trifan, E. (2014). Behavioral Portfolio Theory and Investment Management. In $\mathrm{H}$. K. Baker \& V. Ricciardi (Eds.). Investor Behavior - The Psychology of Financial Planning and Investing (pp. 421438). Hoboken, New Jersey: John Wiley \& Sons, Inc. doi. org/10.1002/9781118813454.ch23

Ricciardi, V. (2008). Risk: Traditional finance versus behavioral finance. In F. J. Fabozzi, (Ed.). Valuation, Financial Modeling, and Quantitative Tools (pp. 11-38). John Wiley \& Sons.

Shefrin, H. (2008). A Behavioral Approach to Asset Pricing. USA: Elsevier Inc.

Shefrin, H. (2015). The behavioral paradigm shift. Revista de Administração de Empresas, 55(1), 95-98. doi.org/10.1590/ S0034-759020150109

Shefrin, H. (2016). Behavioral Risk Management: Managing the Psychology That Drives Decisions and Influences Operational Risk. USA: Palgrave Macmillan.

Shefrin, H., \& Statman, M. (1994). Behavioral capital asset pricing theory. Journal of Financial and Quantitative Analysis, 29(3), 323-349. doi.org/10.2307/2331334

Shefrin, H., \& Statman, M. (2000). Behavioral portfolio theory. Journal of Financial and Quantitative Analysis, 35(2), 127-151. doi.org/10.2307/2676187
Simon, H. A. (1955). A behavioral model of rational choice. The Quarterly Journal of Economics, 69(1), 99-118. doi. org $/ 10.2307 / 1884852$

Slovic, P., Finucane, M. L., Peters, E., \& MacGregor, D. G. (2007). The affect heuristic. European Journal of Operational Research, 177, 1333-1352. doi.org/10.1016/j.ejor.2005.04.006

Statman, M. (2008). What is behavioral finance? In F. J. Fabozzi (Ed.). Handbook of Finance (pp. 79-84). Hoboken, NJ: John Wiley \& Sons, Inc. doi.org/10.1002/9780470404324.hof002009

Statman, M. (2014). Behavioral finance: Finance with normal people. Borsa Istanbul Review, 14, 65-73. doi.org/10.1016/j. bir.2014.03.001

Statman, M. (2017a). Behavioral asset pricing: Asset pricing for normal people. The Journal of Portfolio Management, 44(1), 5-9. doi.org/10.3905/jpm.2017.44.1.005

Statman, M. (2017b). Behavioral portfolios: Portfolios for normal people. Excerpt from Finance for Normal People: How Investors and Markets Behave, Oxford University Press.

Todorović, M. (2011). Psihologija i finansijski menadžment bihevioralne korporativne finansije. Ekonomika preduzeća, 59(3/4), 275-287.

Primljeno 28. oktobra 2019, nakon revizije, prihvaćeno za publikovanje 23. decembra 2019. Elektronska verzija objavljena 25. decembra 2019.

Miljan Leković je docent na Fakultetu za hotelijerstvo i turizam u Vrnjačkoj Banji Univerziteta u Kragujevcu, gde je angažovan na nastavnim predmetima Osnovi ekonomije i Nacionalna ekonomija. Doktorirao je na Ekonomskom fakultetu Univerziteta u Kragujevcu. Oblast njegovog naučnog interesovanja je finansijska ekonomija. 


\title{
BEHAVIORAL PORTFOLIO THEORY AND BEHAVIORAL ASSET PRICING MODEL AS AN ALTERNATIVE TO STANDARD FINANCE CONCEPTS
}

\author{
Miljan Lekovic \\ Faculty of Hotel Management and Tourism in Vrnjačka Banja, University of Kragujevac, The \\ Republic of Serbia
}

The growing gap between the standard finance theory and practice has made way for the emergence of new theories and development of new asset pricing models. Behavioral economists have seized this opportunity to promote their ideas and thus develop behavioral finance theory as an antithesis to standard finance theory, behavioral portfolio theory as an antithesis to modern portfolio theory and behavioral asset pricing model as an antithesis to the standard finance asset pricing models. The paper aims to illustrate these new theoretical frameworks, given the absence of research on the national level relating to the behavioral portfolio theory and behavioral asset pricing model. The objective is to explain key features of behavioral portfolio theory and behavioral asset pricing model by means of conducting comparative analysis of the mentioned theory and its model and the standard finance concepts and models. By using the qualitative research methodology, the author concludes that the behavioral portfolio theory and behavioral asset pricing model, by incorporating psychological factors, complement the conventional finance concepts and bring finance theory closer to reality, however, it is still too early and somewhat exaggerated to talk about the superiority of these new theoretical frameworks in relation to the modern portfolio theory and conventional asset pricing models, which is also the main finding of the research.

Keywords: behavioral finance, psychological factors, mental account, utilitarian benefits, expressive benefits, emotional benefits

JEL Classification: G40, G41 